\title{
The Free Dacian settlement of Arad (Site B_06). PRELIMINARY CONSIDERATIONS
}

VITALIE BÂRCĂ, ROBERT GINDELE

\section{Rezumat: Așezarea dacilor liberi de la Arad (Sit B_06). ConsiderațiI Preliminare}

Obiectul articolului de faţă este o prezentare preliminară a cercetărilor arheologice preventive, datorate construcției Autostrăzii Arad-Timişoara, efectuate în anul 2010 în situl B_06. Suprafața investigată era situată pe tronsonul Arad-Seceani al autostrăzii Arad-Timișoara, în porțiunea km $15+490-15+780$. În urma cercetărilor de suprafață s-a constatat că este vorba de o așezare de mari dimensiuni ce se află atât pe ductul autostrăzii, cât şi la vest şi est de aceasta. În urma cercetărilor arheologice efectuate pe suprafața sitului BO_6 în limitele perimetrul ductului autostrăzii au fost identificate şi cercetate exhaustiv $\mathbf{1 3 2}$ unități stratigrafice, dintre acestea trei fiind morminte de inhumație aparținând sarmaților.

Din totalul complexelor cercetate, $\mathbf{1 0 6}$ au fost descoperite în jumătatea nordică a suprafeței cercetate, iar cele trei morminte, alături de un alt complex, în partea de mijloc a suprafeței afectate de proiect. Mormintele de inhumație sunt izolate de cele 106 complexe din partea de nord a suprafeței investigate, dar şi de cele $\mathbf{2 2}$ situate la sud de acestea.

Cele 106 complexe aparţin unei aşezări dacice ce se datează în linii mari în sec. II - începutul sec. III p. Chr., mormintele se datează la sfârșitul sec. II - primele decenii ale sec. III p. Chr., iar complexele descoperite în jumătatea sudică a suprafeței cercetate aparţin unui alt nivel cronologic şi cultural (sec. IV-V p. Chr.).

\section{ABSTRACT:}

The object of this article is to preliminary present the rescue archaeological excavations prior to the construction of the Arad-Timişoara Highway, conducted in 2010 on-site B_06. The investigated area is located on the AradSeceani highway section, in the $\mathrm{km} \mathrm{15+490-15+780} \mathrm{stretch.} \mathrm{The} \mathrm{field} \mathrm{research} \mathrm{concluded} \mathrm{the} \mathrm{site} \mathrm{was} \mathrm{a} \mathrm{large}$ settlement lying both on the highway route as well as to its west and east. The archaeological investigations carried out within the area of site $B 0 \_6$ and the perimeter limits of the highway route identified and comprehensively examined 132 stratigraphic units, of which three are Sarmatian inhumations.

Of the total researched features, $\mathbf{1 0 6}$ were discovered in the northern half of the investigated area, while the three graves, together with another feature, lay midway through the project area. The inhumations lay isolate from the 106 features from the northern side of the investigated area, but also from the $\mathbf{2 2}$ located southward as well.

The 106 features belong to a Dacian settlement broadly dated to the 2nd - early 3rd century AD, while the graves date to late $2 \mathrm{nd}$ - first decades of the $3 \mathrm{rd}$ century $\mathrm{AD}$, the features discovered in the southern half of the investigated area belonging to another chronological and cultural level (the 4th -5 th century AD).

CUVINTE CHEIE: așezare, daci liberi, epocă romană, Mureș, Banat, Arad, Tisa Nouă

KEYWORDS: settlement, Free Dacians, Roman period, Mureș, Banat, Arad, Tisa Nouă

In the summer-autumn of 2010, with the occasion of the rescue archaeological excavations conducted prior to the construction of the Arad-Timişoara Highway, several archaeological sites were investigated. Most were identified in 2007, following the field research carried out by colleagues with the Arad Museum Complex (Arad) and the National Museum of Banat (Timișoara). Among these sites, there is also site coded B0_61 (Fig. 1). It was investigated during August 16 - September 20, 2010, under contract no. 976 din 30.06.2010, the beneficiary being SC Tomis Research Center SRL (Partnership FCC Construcciones SA - Astaldi SpA). The investigated area lay on the Arad-Seceani section of the Arad-Timişoara highway, by km 15+490-15+780 (Fig. 3).

\footnotetext{
For details regarding the site identifications and finds from its area see Bârcă et al. 2011, 239-242.
} 
The site was located on a high terrace nearby the Tisa Nouă Valley, oriented north-south on the long axis. The terrace was situated at ca. 5-6 km south (in a straight line in the north-south direction) the Mureş River, ca. $2.2 \mathrm{~km}$ east (in a straight line) from road E671 linking Arad to Timişoara and ca. $3.5 \mathrm{~km}$ north-west the place at Tisa Nouă. The settlement was bordered at the slope base on the southern side by the Tisa Nouă Valley. The location region lies south of the Lower Mureş on the territory of Banat ${ }^{2}$ (Fig. 1, 4).

The 2010 archaeologically researched area was surveyed, together with the entire area of the Arad-Seceani Highway

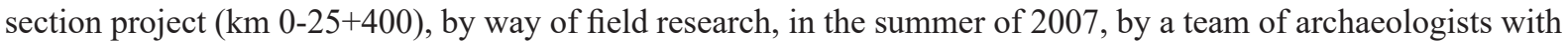
the Arad Museum Complex (Arad). The aim of these field investigations carried by our Arad-based colleagues was to identify the archaeological remains and draft the project for the rescue archaeological excavations for the area where the Highway would be constructed.

Subsequent to these, on a relatively large area stretching east and west from the Highway route handmade and wheel-thrown pottery fragments, tuff grinder fragments and adobe pieces were discovered. Based on these finds, the settlement was dated to the $3^{\text {rd }}-5^{\text {th }}$ century AD. The large distribution of the archaeological material led to the conclusion that it was one of the largest settlements of the period, having a clearly defined surface. Furthermore, it was noted that the site contained the defining elements of a prosperous agricultural community. The same field research also noted that most part of the settlement lay east of the Highway route. From there a significant quantity of handmade and wheel-thrown pottery was collected, also tuff grinder fragments and adobe pieces.

It is also worth mentioning that the site identified in 2007 was not investigated by rescue archaeological excavations until the start date of the civil works on the Arad-Seceani route of the Arad-Timişoara highway.

The field-walks undertaken a few days prior to the commencement of the proper archaeological excavations noticed this was a large settlement (ca. $300 \mathrm{~m}$ long and ca. $250 \mathrm{~m}$ wide) lying both on the highway route $(\mathrm{km}$ 15+490-15+780), as well as to its west and east. In addition, most part of the settlement lay east the route of the future Highway. The archaeological material, collected in large quantities subsequent to the field-walks contained: handmade and wheel-thrown pottery fragments, tuff grinder fragments, adobe pieces etc. The very large distribution of the material over a spread area confirmed we were dealing with a rather large settlement.

The site provided first specific data regarding its stratigraphy in the first days of the field archaeological research. It was generally observed that practically, the project area had no archaeological level, identified features were lying, with the exception of the three inhumations, almost exclusively at depths more than 50-60 cm from topsoil. The removal of the vegetal and farming layer, ca. $40-50 \mathrm{~cm}$ thick, was done by mechanical means ${ }^{3}$. Since the clear delimitation of the features was made impossible by the farming layer base (most of the features were delimited at depths more than $60 \mathrm{~cm}$ from topsoil), another thin layer was mechanically removed in certain areas. Then a further 10-15 cm thick layer was removed by hand, followed by successive surface cleaning (with the aid of 55 unskilled labourers made available by the highway contractor), down to a depth at which the features could be identified, investigated and the data properly recorded ${ }^{4}$.

The archaeological excavations conducted during August 16 - September 20, 2010 within the area of site B0_6

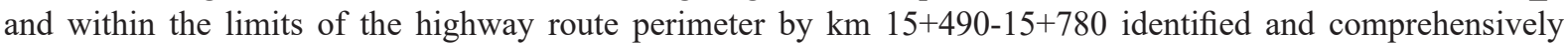
investigated 132 stratigraphic units, of which three are Sarmatian inhumations ${ }^{5}$.

The stratigraphic column was broadly identical on the entire project area. The vegetal layer, together with the farming layer, was 40-50 cm thick, occasionally even $60 \mathrm{~cm}$, being dark-grey and of relatively compact consistency. Midway and southward of the investigated area (between $\mathrm{km} \mathrm{15+600-15+780),} \mathrm{in} \mathrm{the} \mathrm{same} \mathrm{layer,} \mathrm{were} \mathrm{discovered}$ handmade and wheel-thrown pottery fragments, tuff grinder fragments and adobe pieces etc. On certain stretches of the investigated area, there also existed a black, very hard clay layer, reaching here and there a thickness of

\footnotetext{
The Banat is a historical province that today includes areas from Romania, Serbia (Serbian Banat) and a small part of Hungary. Banat's natural borders are the rivers Mureş to the north, the Tisza to the west, the Danube to the south and the tectonic couloir Timiş-Cerna-Mehadia to the east. In Romania, the Banat includes the counties of Arad, Timiş and CaraşSeverin, as well as the south-west corner of Mehedinţi County (Rusu 2007, 21-22).

3 The project area surface was mechanically uncovered (embankment scoop excavator), in $10 \mathrm{~cm}$ thick layers, followed by manual earth removal.

4 Total excavated and researched area was of $14579.71 \mathrm{~m}^{2}$.

5 The three graves were isolated from the rest of the features, being identified midway through the project area, by $\mathrm{km}$ $15+660-15+670$ of the future highway.
} 
20-30 cm. In a few places of the black clay layer's upper part were discovered small pottery fragments. This layer was followed by a yellowish-red, compact very hard clay layer, emerging at 70-80 cm deep from topsoil, in which were clearly delimited most of the researched features.

Of the total investigated features, 106 were discovered in the northern half (between km 15+510-15+630) of the investigated area (Fig. 3). These mainly clustered on the west and east sides of the area, furthermore certifying that the settlement stretched both westwards and eastwards the route of the future highway, thus confirming the results of the field research carried out by our colleagues with the Arad Museum Complex in the spring of 2007 and those with the Institute of Archaeology and Art History of Cluj-Napoca, from the period prior the start date of the proper archaeological research.

The three graves, discovered in poor preservation state, were identified beside $\mathbf{C x} 45^{6}$ midway the project area ( $\mathrm{km}$ 15+660-15+670). The latter was discovered at a small distance from $\mathbf{G} \mathbf{3}^{7}$ (Fig. 3). The inhumations are isolated from the $\mathbf{1 0 6}$ complexes from the northern side of the investigated area, yet also from the $\mathbf{2 2}$ lying southwards $(\mathrm{km}$ 15+678-15+780), divided from the latter by $\mathbf{C x ~ 1 2 9}$, a W-E oriented ditch, identified on a length of $25.6 \mathrm{~m}$ and width of $0.58 \mathrm{~m}$ (see Fig. 3).

The recently published inhumations are of Sarmatian origin and form a group ${ }^{8}$. They are contemporary and date based on the grave goods to the late $2^{\text {nd }}-$ first decades of the $3^{\text {rd }}$ century $\mathrm{AD}^{9}$. Such date is confirmed by the presence in $\mathrm{G} 3$ of a knee brooch with the spring inserted through a half-roll ${ }^{10}$ (type Cociș 19a6alb) whose use frames to the time span between the seventh decade of the $2^{\text {nd }}$ century $\mathrm{AD}$ and the first decades of the $3^{\text {rd }}$ century $A D^{11}$. From $\mathrm{G} 2$ come beads, yet also a trapezoid iron prong bronze buckle ${ }^{12}$, while at $1 \mathrm{~m}$ from $\mathrm{G} 1$ was discovered a round flat disc mirror ${ }^{13}$.

Regarding the features discovered in the south area $(\mathrm{km} \mathrm{15+680-15+780)}$ the three Sarmatian graves, it may be argued that the discovered archaeological material, which comprised intact or fragmentary slow wheel-thrown vessels, belong to another chronological and cultural layer (the $4^{\text {th }}-5^{\text {th }}$ century AD), different from the northern one, which we shall address in a future study.

\section{State of research of the Barbarian settlements from the Banat and Arad region}

Only a few Barbarian settlements were archaeologically investigated, several hundred being identified by fieldwalks or chance finds ${ }^{14}$. Until 1989, systematic excavations were carried out at Hodoni-Pustă and TimișoaraFreidorf, in the latter these being furthered in the 1990s and early 2000s. The excavation system of the time consisted of excavating parallel trenches, besides small surfaces where various features emerged. Thus, at HodoniPustă in 1979-1984 on a $900 \mathrm{~m}^{2}$ area were investigated 40 features ${ }^{15}$, at Timișoara-Freidorf between 1986-1989, 1992-1998 and 2000-2002 on an approximately $450 \mathrm{~m}^{2}$ area were examined almost 50 features ${ }^{16}$. Beside these two systematic investigations at Grădinari-Săliște between 1963-1964, 1985, were identified six features (of which a pottery workshop with work pit and three kilns) ${ }^{17}$, while at Moldova Veche-Vlaskicrai were researched four houses ${ }^{18}$. In Arad County, the archaeological research of Roman Age settlements was limited to rescue interventions or small size investigations (Arad-Grădişte five storage pits ${ }^{19}$, Arad-Ceala I one pottery kiln ${ }^{20}$, Cicir-La gropi 13 sunken houses and pits ${ }^{21}$, Felnac-Complexul porcine a few sunken houses and domestic pits ${ }^{22}$, Sâmbăteni-Către

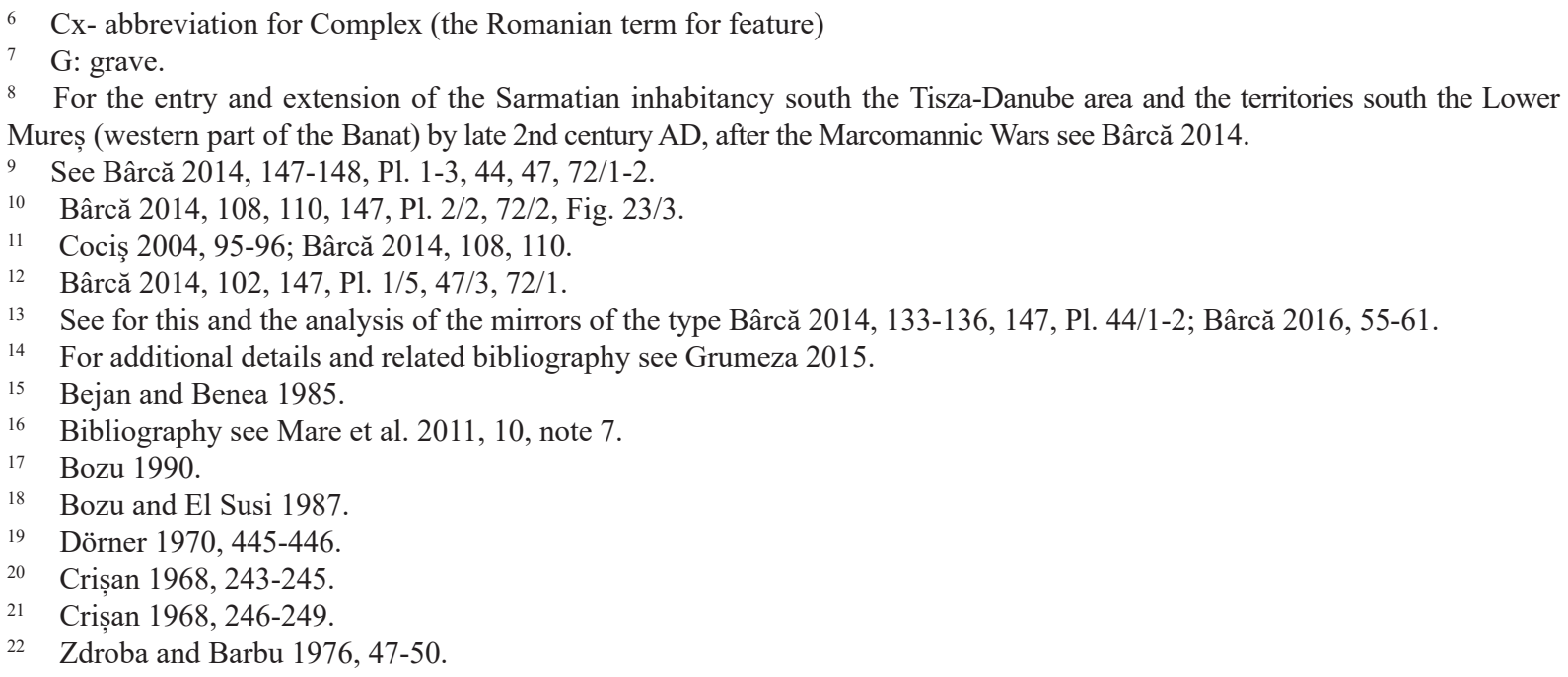


Cicireni in the profile of a pipeline ca. 20 sunken houses ${ }^{23}$, Sântana-CAP La Vii one sunken house and six storage pits $^{24}$, Șeitin-La tăietură a few sunken houses ${ }^{25}$ ). The interest for the research of the Barbarian settlement remained little also in the 2000s. In 2004 at Foieni-Selişte archaeological research was conducted on a $70 \mathrm{~m}^{2}$ area, which yielded 13 features ${ }^{26}$.

The research and publication of Barbarian settlements developed in the Banat Plain in Romania along with the intensification of the archaeological research performed on the occasion of large-scale infrastructure projects. At Dumbrăviţa, along the bypass-highway of the City of Timişoara, on a ca. $1000 \mathrm{~m}^{2}$ area were investigated eight archaeological features ${ }^{27}$. From the known site of Timişoara-Freidorf were set in scientific circulation the discovered remains investigated in 2006 prior industrial building works (62 features on 0.5 ha) ${ }^{28}$, while the research in this site still continues due to various industrial developments carried out in the region. From Highway A1 (Arad-Timișoara) were published the research of the settlement at Arad - Sit B0_5, where were discovered and investigated 50 settlement features, storage pits, ovens/smoking facilities and several postholes ${ }^{29}$ and the settlement of Șagu-Sit A1_1, with 14 researched features ${ }^{30}$. Unfortunately, other investigated sites remained until the present unpublished $^{31}$. A good opportunity for the knowledge of the Barbarian settlements from western Romania was represented by the research conducted on the new main railway stretch in Arad County, namely the research of Conop, where within an area of $5296 \mathrm{~m}^{2}$ were identified and investigated 12 features $^{32}$.

Our parallel analysis regarding the discovered feature types and archaeological material must seek for analogies, exceeding the geographical limits of the Banat, within the settlements between the provinces of Dacia and Pannonia. Unfortunately, the publications for this geographical area have been primarily focused on the funerary horizon, although during major road infrastructure projects hundreds of thousands of square meters from the first centuries $\mathrm{AD}^{33}$ Barbarian settlements were archaeologically investigated. The settlements generally developed over the course of the $2^{\text {nd }}-5^{\text {th }}$ century $\mathrm{AD}$, with an often-noticeable spatial extension of the features depending on the chronological development. Nevertheless, it must be mentioned that a chronological framework for these settlements was not yet drafted.

Excavation on a 1.45-hectare area, with 132 features (out of which three graves) seems rather large for today's Romanian archaeology, yet in the Sarmatian Barbaricum are known much larger investigated areas. For example, on the eastern bypass of Budapest, at Üllö, Site 4 and Site 9 were investigated on a 40-hectare area ${ }^{34}$. Unfortunately, research results in these settlements remained in a state of reports, mentions or preliminary publications.

\section{The internal organization of the settlement}

From the point of view of the internal organization of the settlement based on the information yielded by excavations, only minimal assessments are possible to be made. Except for the fact that we likely identified the edges of two pit groups, divided by a more sunken area, the lack of dwellings renders impossible any evaluation of the structure of the household. Although the information is scarce, one should not seek for inhabitancy structures based on well-defined households, but rather on pit groups within the settlements.

The internal structure of the settlement we studied is different from that investigated for instance at TimișoaraFreidorf, where storage pits were excavated nearby the sunken dwellings ${ }^{35}$. The structure of the Arad-Barieră settlement is also different from the settlement here, the researcher interpreting the concentrated features groups as

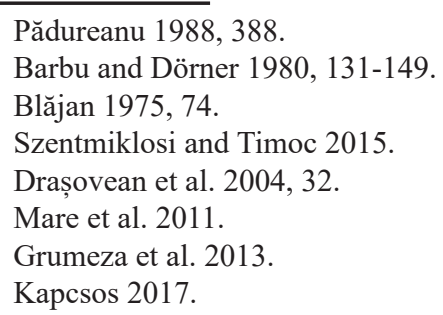
45 stratigraphic units: 34 are of the 3rd - 4th century AD, of which 17 are Sarmatian inhumations, published in 2014 (Bârcă 2014). To these add the two early medieval houses (8th - 9th century AD) with a seasonal house (dwelling?) of the 11th - 13th century and 8 features (possibly modern), of which two are kilns (Bârcă et al. 2011a, 187-192). Murani (14 features), total excavated and researched area was of $20362 \mathrm{~m}^{2}$ (Pîslaru et al. 2011, 202-205).

32 Kapcsos and Mărginean 2020.

3 For 1990s see Vörös 1998, 51 or Vaday 2004.

34 Tari 2006, 42-43.

5 Mare et al. 2011, 196-197. 
forming three distinct settlement units ${ }^{36}$. In the case of other settlements from Banat, investigated on smaller areas, most often by trenches and small surfaces, it is not possible to identify settlement structures based on storage pit

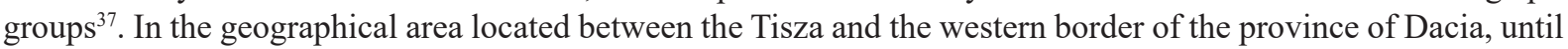
the commencement of the rescue excavations related to constructions, the settlement with the largest investigated area was that of Biharkeresztes Ártánd Nagy- and Kisfarkasdomb, where the digger interpreted the structure as a family-based settlement, with storage pits set up nearby the houses ${ }^{38}$. Once with the road infrastructure development in the Great Hungarian Plain, research was initiated on larger areas of the Barbarian settlements, yet few were published. At Pócspetri, the excavator interpreted the settlement structure based on feature groups, in one case noting a clustering of storage pits, the majority conical ${ }^{39}$. A group of storage pits, somewhat resembling those identified here, was investigated in the Western Plain at Biharea-Grădina SA-Baraj ${ }^{40}$. In the northern area of the Sarmatian inhabitancy block, in one excavation related to the road infrastructure development, at Kompolt was reported a grouping of storage pits on a length of $60 \mathrm{~m}^{41}$. Similar circumstances with those studied here may be reported at Lajosmizse, where a 22 pit cluster was identified ${ }^{42}$.

\section{Feature types}

Typologically, circular or oval pits may be classified according to their profile shape. Although pits were never in the first line of typological analyses of settlements, we believe these must be framed in a well-established typological system during the complete, monographic processing of the research information. We reference here the best-known forms in the specialized bibliography, namely the tronconic pits, where the upper part has a more restricted diameter than the maximum diameter of the feature profile. Maximum diameters may lie either at pit bottoms or at a certain depth, after which they taper again towards the bottom. Also, the lower part of the pits may be straight, lens-shaped or unequal.

The tronconic pits from the settlement discussed here may be classified in two large groups: with pronounced curved walls on the one hand and with less curved walls on the other hand (Fig. 7). In the first class, one can distinguish pits with a straight bottom, of which only one pit falls into the classical type, having the maximum diameter at the base and also an angular closing between walls and base ( $\mathrm{Cx} 85)$. The other type has a maximum diameter in the lower third of the pit (Cx 50,61, 68, 75, 79, 83, 110, 113). The other typological group is characterized by a clear concave base, with maximum diameter in the lower third $(\mathrm{Cx} 53,54,57,60,104)$ or maximum diameter by the midway third $(\mathrm{Cx}$ 96, 97) of the pit. All tronconic pits mentioned above emerge only in the group of features from the eastern part of the investigated area.

Observations on the shape of the storage pits are few in the specialty bibliography concerning the Barbarian settlements from territories lying between the provinces of Dacia and Pannonia. Andrea Vaday noted that tronconic storage pits from earlier Sarmatian settlements (Újhartyán, Kompolt) have their enlarged part smaller and shorter than those in the late Sarmatian settlement, hence comparatively, smaller grain quantities ${ }^{43}$ were deposited there.

\section{Pottery-related issues}

Technologically, the pottery found in the settlement can be categorized in two large groups: handmade pottery, coarse or semi-fine and fast wheel-thrown, fired in an oxidising or reducing atmosphere. The slow wheel-thrown pottery or coarse fast wheel-thrown pottery, specific to the $3^{\text {rd }}-4^{\text {th }}$ century AD settlements in the Great Hungarian Plain is missing. Intact or fragmentary slow wheel-thrown vessels discovered in the features found in the southern half of the investigated area belong to another chronological and cultural level (the $4^{\text {th }}-5^{\text {th }}$ century AD).

The fast wheel-thrown pottery is in the fine or semi-fine class, with the following shapes: bowls, cups, pots and storage vessels. The bowls discovered in the settlement studied here differ from those common in Sarmartian settlements, which in the great majority of the cases have thickened rim and hemispherical or in open-angle body ${ }^{44}$. The bowls presented here are grey, with wide rims, everted and bent in the upper part (Fig. 8/2-4). These bowls resemble the Dacian platters and emerge rarely in the settlements between Dacia and Pannonia. Very good

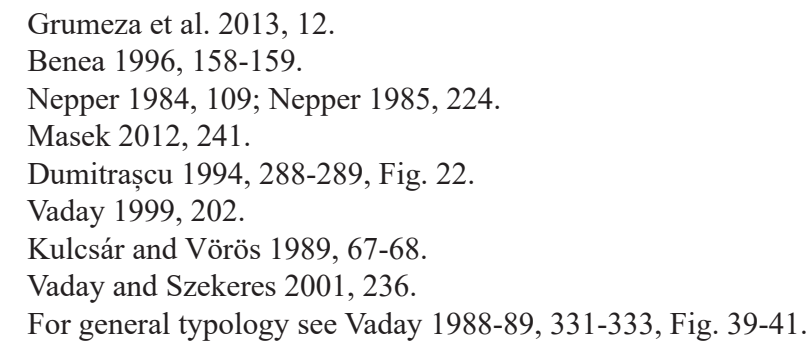


parallels may be reported in settlements with Dacian elements of material culture, like Szegvár-Oromdülö ${ }^{45}$ or Biharkeresztes Ártánd- Nagyfarkasdomb ${ }^{46}$ or the production pottery centre of Medieșu Aurit-Șuculeu ${ }^{47}$. The jug with burnished shoulders in vertical stripes (Fig. 8/5) is found in large numbers in the Barbarian environment between the Tisza and the borders of Roman Dacia, with good parallels at Biharkeresztes-Kisfarkasdomb ${ }^{48}$ as well, in contexts with handmade pottery decorated with embossed plastic ornaments. Although the archaeological material discovered in the site here is fragmentary, we may still note the lack of larger jugs and vessels designed to store liquids. The pots and large storage vessels made of fine or semi-fine fabric are difficult to frame typologically since limits between large pots or small storage vessels are difficult to identify (Fig. 8/7). These vessel types were functionally similar, larger fine fabric pots being not designed for cooking but only as tableware and food storage. Larger storage vessels of semi-fine fabric with thick walls, T-shaped wide rims, produced on large scale in the pottery production centre of Medieșu Aurit, are lacking from the Arad settlement (Site $B \_06$ ). The types there frame the known forms of the Sarmatian settlements from the Tisza Plain. Storage vessels emerged in the Sarmatian pottery of the Tisza Plain once with the shift from nomad living to sedentary and the emergence of the settlements. Based on the finds from the Szolnok County, Andrea Vaday differentiated two basic types: with broad mouth, without marked shoulder and with smaller mouth diameter, with shoulder. To date, a clear chronological relevance for these two types could not be established ${ }^{49}$.

The handmade pottery continues, from the technological production point of view, the classical Dacian tradition and typologically frames in the repertory of shapes from respective period. The two basic forms are most often vessels decorated with applied plastic decoration (knobs, alveoli belt) (Fig. 9/3-4; 10) and the so-called Dacian cup (Fig. 9/2) or dish (Fig. 9/1). Besides these two basic forms also emerge miniature vessels, of which some decorated with plastic knobs or alveoli belts. An uncommon vessel comes from feature 91 (Fig. 11). It is biconical with an umbo by the base. In shape and rim decoration, it has a good parallel in grave 1374 from the cemetery at Poienești, a singular form in respective cemetery interpreted by the researcher as a possible duplicate of the wheelthrown urn from another grave ${ }^{50}$. The presence of umbos by vessel bases is a rare phenomenon in the $2^{\text {nd }}$ century Barbaricum pottery making. A similar case is found in the potters' settlement of Medieșu Aurit-Șuculeu (northwestern Romania) coming from the first half of the $2^{\text {nd }}$ century AD context. ${ }^{51}$.

Pots with plastic knobs, applied garland or alveoli belt were believed, in the archaeological material of the Tisza Plain, of Dacian origin, not adopted by the Sarmatian pottery making ${ }^{52}$. These vessels are present in the area inhabited by Barbarian populaces between the provinces of Dacia and Pannonia, emerging in different contexts, in both settlements and inhumations. Handmade vessels decorated with plastic ornamentations are not constant in $2^{\text {nd }}-3^{\text {rd }}$ century Sarmatian settlements. They are missing for example from the settlement at Pócspetri ${ }^{53}$. From the settlement at Ártánd-Nagyfarkasdomb emerges a large number of pottery decorated with alveoli belt ${ }^{54}$, alveoli garlands ${ }^{55}$, plastic knobs with ${ }^{56}$ or without alveoli ${ }^{57}$, yet, although the material is fragmentary, no Dacian cup was discovered. Circumstances are similar also in the neighboring settlement of Ártánd-Kisfarkasdomb. By the western border of the Banat, in the settlement of Szegvarr-Oromdülő, among pottery fragments coming from ca. $550-600$ vessels, more than half are from handmade vessels, only a single fragment being decorated with alveoli belt $^{58}$, while Dacian cups are missing.

\section{Dacian tradition pottery in the Barbarian area between the provinces of Dacia and Pannonia}

In 1970, the Hungarian researcher Zsolt Visy catalogued Dacian finds from Hungary, focusing exclusively on handmade pottery ${ }^{59}$. The necessity to nuance such an approach, by including also the wheel-thrown pottery or

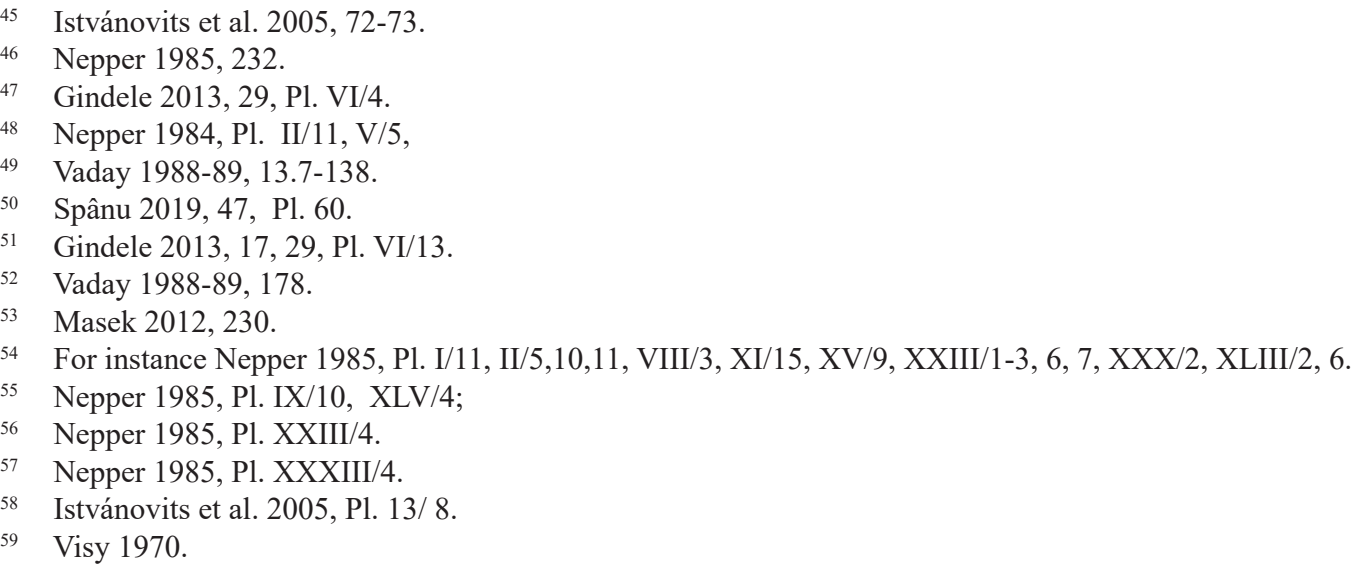


possible metal pieces was expressed two decades later by Andrea Vaday ${ }^{60}$. Today, after another two decades, there is no general archaeological approach to the issue of the present Free Dacian material culture in the territories located between the provinces of Dacia and Pannonia. One of the main issues regarding the presence of Dacian pottery in the territory between the province of Dacia and Tisza is their origin. For the lack of very clearly datable contexts prior to the arrival of the Sarmatians, it is impossible to say whether these items mirror a continuous presence of the Dacians in this area. Vaday Andrea believes the Dacians controlled this area rather politically and less by habitation ${ }^{61}$. Based on the processing of the finds from Kompolt, Andrea Vaday concluded that a Free Dacian population was displaced from the Upper Tisza area subsequent to the entry of the Vandals in the region ${ }^{62}$. In the settlement of Gyoma 133, investigated on a $14700 \mathrm{~m}^{2}$ area, emerging Dacian finds were placed to the last third of the $2^{\text {nd }}$ century $\mathrm{AD}$, once with the development of metalworking there ${ }^{63}$. The presence of Dacian or of Dacian tradition pottery was reported in the Sarmatian settlement of Újhartyán, with a 25-30 years chronological gap from that of Gyoma $133^{64}$.

Discussions on Dacian pottery from inhumations started from the Kakasszék finds, where Mihály Párducz assumed an existing Dacian chronological horizon, prior to the arrival of the Sarmatian population ${ }^{65}$. Later, once with the multiplication of the finds, such view was disputed, the presence of the Dacian pottery being confirmed in the context of several Sarmatian graves ${ }^{66}$. Relatively recently, the presence of handmade vessels in the Sarmatian cemetery of Békéssámson- Erdőháti halom was related to a Dacian tradition in the local pottery making. According to the author of the publication, these vessels were modeled locally in order to be deposited in inhumations, which according to the rite and ritual, as well as the other grave goods, are undoubtedly Sarmatian in origin. The tradition of Dacian pottery on a local level still exists in the $2^{\text {nd }}$ century $\mathrm{AD}$, with the third and fourth generation of Sarmatians after their arrival east of the Tisza ${ }^{67}$.

\section{Metal finds}

The ring in feature 41 is made of a single bronze wire, rectangular in cross-section, with overlapping ends. One of the ends is widened. The ring surface is decorated with oblique incised lines reminiscent of fir three motif ornaments (Fig. 8/1). A close parallel, however in silver and with both ends widened, comes from a Sarmatian grave oriented S-N from Martfü-Zsófia Major (Mid Tisza). Based on the artefacts beside which it was discovered within the grave, it was dated to the $2^{\text {nd }}$ century $\mathrm{AD}$, the lack of good parallels in the material culture environment of the Sarmatian Iazyges from the Great Hungarian Plain being mentioned when published ${ }^{68}$. Another very typologically similar ring with that of Arad, yet silver made, was discovered in grave 7 at Tiszavasvári-Városföldje Jegyzö tag. The cemetery, to which the grave belongs, dates to the late $2^{\text {nd }}$ century - early $3^{\text {rd }}$ century $\mathrm{AD}^{69}$. The type of spiraled ring emerges rarely in Dacia, a silver exemplar with decoration close to that on the specimen in feature 41 from the Arad settlement coming from among the finds at Apulum ${ }^{70}$.

Metalworking in the settlement studied here is reported by the iron pliers discovered in feature 111 (Fig. 12). Traces of metalworking are rather rare in the Barbaricum between the provinces of Dacia and Pannonia. According to Andrea Vaday, Sarmatian Iazyges metallurgy relied early by their presence in the Carpathian Basin on Celtic tradition and emerged in the northern area of the Great Hungarian Plain. In the case of the Gyoma 133 settlement, ironworking started after the Marcomannic Wars, once with the emergence of the Dacian material culture elements. Such industry is archaeologically mirrored by present $\operatorname{slag}^{71}$. At Tiszaföldvár, in the $2^{\text {nd }}$ century AD, operated a workshop making bronze objects, including brooches. In this case, there was identified the proper workshop with raw material, slag, casting spoons and crucibles ${ }^{72}$. A smith's workshop was identified in a late Sarmatian settlement at Nyíregyháza-Rozsrét szöllö too, where a large quantity of slag was discovered in the feature, partially pressed on the floor. A pit within the feature was interpreted as a hub hole onto which the anvil was attached.

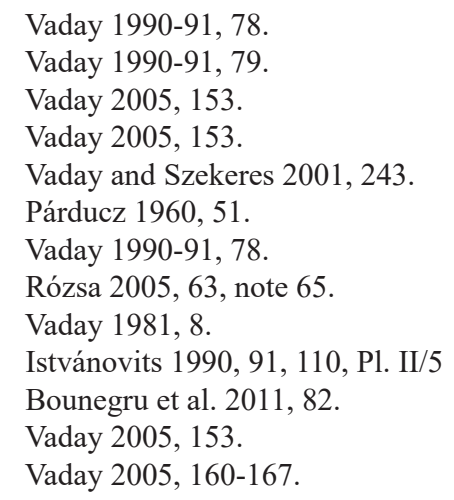


From the filling of the feature come several iron object pieces, unfortunately strongly corroded, of which some might be ironsmith tools ${ }^{73}$. Slag and small casting spoons were discovered at Nagymágocs-Pap tanya ${ }^{74}$, while at Biharkeresztes was supposed the existence of an ironsmith workshop ${ }^{75}$. Although metalworking traces are obvious in Sarmatian settlements as well, nevertheless parallels for the pliers in feature 111 must be sought in the northwestern area of Romania, in the Dacian-Germanic environment of the first half of the $2^{\text {nd }}$ century AD of the settlement at Csengersima-Petea ${ }^{76}$. The number of blacksmith pliers in the classical Dacian culture is large. The type we discovered, with a short and strongly curved mouth falling into type VII after Iaroslavschi, has parallels in Western Europe ${ }^{77}$.

\section{Preliminary conclusions}

In the pages of this preliminary study, we wished to introduce in scientific circulation a few preliminary pieces of information on the rescue archaeological excavations carried out in the settlement here, prior to the construction of the Arad-Timişoara Highway, Arad-Seceani section, site $B \_06$. Unfortunately, owing to the highway route, knowledge is limited to only a settlement segment that could be excavated. Thus, is it impossible to clarify whether the over one hundred features discovered and researched in the northern side of the investigated area represent a distinct settlement or a chronological stage of a settlement evolving over the course of several centuries and ending with features dated to the late $4^{\text {th }}$ century - early $5^{\text {th }}$ century AD, identified in the southern side of the investigated area. The highway route also allowed the study by excavations of only a limited segment of the internal layout of the settlement. In this case, we could not identify any dwellings around which we could have outlined household units.

Until the complete processing of the features and archaeological material, we may report a few important aspects related to this settlement. Firstly, it is important to date the features to the $2^{\text {nd }}-$ early $3^{\text {rd }}$ century AD. Settlements framing this chronological span are rare in the Tisza Plain, the few mentioned for pottery form parallels differentiating from the material culture point of view from that studied here. In the Arad settlement Site $B \_06$, for now, the elements specific to the material culture of the Sarmatian Iazyges at the pottery level are missing. Concurrently, almost all forms are paralleled in settlements and cemeteries of the Free Dacians from extra-Carpathian territories. In our view, circumstances in the Arad settlement (Site $B \_06$ ) resemble from many points of view those at Medieșu Aurit-Şuculeu ${ }^{78}$. Over the course of several systematic archaeological research campaigns, at least until the current research state, only pottery forms specific to the material culture of the Free Dacians were discovered. The settlement at Medieșu Aurit is located in another cultural environment compared to that of Arad, in the Someș Plain. There, during the $2^{\text {nd }}-4^{\text {th }}$ century AD existed a Daco-Germanic habitat of mosaic type, with settlements in which a mixed material culture emerges, with material culture elements of the Free Dacians and the bearers of the Przeworsk culture. It is certain though that in the current state of research, the single settlement where material culture elements belonging exclusively to the Free Dacians emerge is that of Medieșu Aurit-Şuculeu. Although research of the Barbarian settlements on the territory of Banat and Crișana remains behind that of cemetery research, it is very likely that with successive publishing of the large-scale archaeological investigations, to sketch a habitat with specificities resembling those from north-western area of Romania, with mainly Free Dacian and Sarmatian material culture constituents.

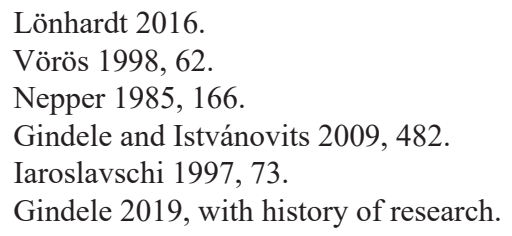




\section{BIBLIOGRAFIE}

Barbu, M. and Dörner, E. 1980. Cercetările arheologice de la Sântana. Campania 1979. Ziridava XII: 131-150.

Bârcă, V. 2014. Sarmatian vestiges discovered south of the Lower Mures River. The graves from Hunedoara Timişană and Arad. Cluj-Napoca: Mega Publishing House.

Bârcă, V. 2014a. Returned foot exterior chord brooches made of a single metal piece (Type Almgren 158) recently discovered in the Western Plain of Romania. Notes on origin and chronology. Journal of Ancient History and Archaeology 1/2: 21-39, DOI: 10.14795/j.v1i2.50

Bârcă, V. 2016. A disk mirror recently discovered South the Lower Mureș. Journal of Ancient History and Archaeology 3/3: 55-61. DOI:10.14795/j.v3i3.198

Bârcă, V. and Cociş, S. 2013. Sarmatian Graves Surrounded by Flat Circular Ditch Discovered at Nădlac (Arad County, Romania). Ephemeris Napocensis XXIII: 31-50.

Bârcă, V., Ursuţiu, A., Cociş, S. I., Stăncescu, R. E., Țuţuianu, C. D., Irimuş, L., Cociş, Al., Sălcudean, C., Bondric, A. and Brehuescu, Al. 2011. Tisa Nouă, com. Fântânele, jud. Arad Punct: tronson Arad-Seceani, km 15+490-15+780 (situl B0_6) (Autostrada Arad-Timişoara). Cronica Cercetărilor Arheologice din România. Campania 2010: 239-242. Sibiu: Muzeul Naţional Brukenthal.

Bârcă, V., Ursuţiu, A., Cociş, S. I., Stăncescu, R. E., Țuţuianu, C. D., Irimuş, L., Cociş, Al., Sălcudean, C., Bondric, A. and Brehuescu, Al. 2011. Hunedoara Timişană, com. Şagu, jud. Arad, Punct: Autostrada AradTimişoara, tronson Arad-Seceani, km 23+170 - 23+690 (siturile B0_7-B0_8). Cronica Cercetărilor Arheologice din România, Campania 2010: 187-192. Sibiu: Muzeul Național Brukenthal.

Bejan, A. and Benea, D. 1985. Şantierul arheologic Hodoni Pusta. Raport preliminar 1979-1984 (Ausgrabungen in Hodoni-Pusta). Banatica 8: 187-199.

Benea, D. 1996. Dacia sud-vestică în secolele III-IV. Timișoara: Editura de vest.

Blăjan, M. 1975. Descoperiri dacice și sarmatice de la Șeitin (jud. Arad). Crisia 5: 69-85.

Bounegru, G, Ciobanu, R., Ota, R. and Anghel, D. 2011. Lux, util și estetic la Apulum. Podoabe și accesorii vestimentare. Catalog de expoziție. Alba Iulia: Editura Altip.

Bozu, O. 1990, Aşezarea daco-romană de la Grădinari -"Sălişte" (jud. Caraş-Severin) (Die dako-romanische Siedlung von Grădinari-“Sălişte” (Kreis Caraş-Severin). Banatica 10: 147-186.

Bozu, O. and El Susi, G. 1987. Aşezarea romană târzie de la Moldova Veche Punctul „Vinograda-Vlaşkicrai” (județul Caraş-Severin) (Die spätrömische Siedlung von Moldova Veche „Vinograda-Vlaskikrai” (Kreis CaraşSeverin) ). Banatica 9: 239-270.

Cociş, S. 2004. Fibulele din Dacia romană / The Brooches from Roman Dacia. Cluj-Napoca: Mega Publishing House.

Crișan, I., H. 1968. Continuitatea dacică în Câmpia Aradului (La continuité dace dans la plaine d'Arad). Apulum VII: 241-260.

Dörner, E. 1970. Cercetări și săpături arheologice în județul Arad (rechersches et fouilles archéologiques dans le département d'Arad). Materiale și cercetări arheologice IX: 445-466.

Drașovean, F., Mare, M., Tănase, D., Benea, D., Muntean, M., Crânguș and M., Micle, D. 2004. Săpături arheologice preventive de la Dumbrăvița. Timișoara: Editura Eurostampa.

Dumitrașcu, S. 1994. Biharia. Săpături arheologice (1973-1980) I. Oradea: Editura Universităţii din Oradea.

Gindele, R. 2013. Die Problematik der barbarischen Siedlungen im NordWesten Rumäniens zwischen der Gründung der Provinz Dakien und den Markomannenkriegen. Ephemeris Napocensis XXIII: 11-30.

Gindele, R. 2019. Centrul de producție ceramică de la Medieşu Aurit. Istoricul cercetărilor şi rezultate primare ale noilor cercetări. Studii și Comunicări Satu Mare, Seria arheologie 31-32 (2015-2016): 53-72.

Gindele., R. and Istvanovits, E. 2009. Die römerzeitliche Siedlung von Csengersima-Petea. Satu Mare: Editura Muzeului Sătmărean.

Grumeza, L. 2015. Settlements from the $2^{\text {nd }}$ - early $5^{\text {th }}$ century AD in Banat (I). State of research and the interpretation of the discoveries from Romania. Journal of Ancient History and Archaeology 2/4: 75-77.

Grumeza, L., Ursuțiu, A. and Copos, G. 2013. Arad "Barieră". Cercetări arheologice preventive intr-un sit de epocă sarmatică / Arad "Barieră". Rescue excavation in a Sarmatian period site. Cluj-Napoca: Mega Publishing House. 
Iaroslavschi, E. 1997. Tehnica la daci. Bibliotheca Musei Napocensis XV. Cluj-Napoca: Muzeul Naţional de Istorie a Transilvaniei.

Istvánovits, E. 1990. A Felső-Tisza-vidék legkorábbi szarmata leletei- 2-3. Századi sírok Tiszavasváriból (The earliest Sarmatian finds of the Upper Tisza region $-2^{\text {nd }}-3^{\text {rd }}$ century burials Tiszavasvári). Nyíregyházi Jósa András Múzeum Évkönyve, XXVII-XXIX (1984-1986): 83-134.

Istvánovits, E., Lőrinczy, G. and Pintye, G. 2005. A Szegvár-oromdűlői császárkori telep. (Die frühkaiserzeitliche Siedlung von Szegvár-Oromdűlö). Móra Ferenc Múzeum Évkönyve - Studia Archaeologica 11: 51-114.

Kapcsos, N. 2017. Urmele unei aşezari din perioada târzie a epocii sarmatice descoperite la Şagu „Sit A1_1”, județul Arad (Traces of a Settlement from the Late Sarmatian-Period discovered in Şagu „, Site A1_1”, Arad County), in Mărginean, F., Stanciu, I., Băcueț-Crișan, D. (eds.) Orbis Medievalis I., Locuirea medievală timpurie din Transilvania și vecinătăți. The Early Medieval Habitation from Transylvania and its Surroundings: 13-44. Arad: Mega Publishig House.

Kapcsos, N. and Mărginean, F. 2020. Egy 4. század végi - 5. század eleji teleprészlet Konop határában. Kontaktzóna vagy kutatási stádium? (Settlement detail near Conop from the late $4^{\text {th }}$-early $5^{\text {th }}$ century A contact zone or just a research stage?), in Bíró, Gy., Pintér-Nagy, K., Szebenyi, T. (eds.) Új nemzedék a szegedi régészeti tanszék tehetséggondozásának elmúlt évtízedei. Ünnepi kötet B. Tóth Ágnes, Kulcsár Valéria, Vörös Gabriella és Wolf Mária tiszteletére. Monográfiák a szegedi tudományegyetem régészeti tanszékéröl 7: 187-214. Szeged: SZTE BTK Régészeti Tanszékének kiadványa.

Kulcsár, V. and Vörös, I. 1989. Szarmata telep Lajosmizse határában. Leletmentés az M5 útnál. (Adalékok a római kori utakhoz) (Sarmatische Siedlung in der Gemarkung von Lajosmizse. Fundrettung an der Autobahn M5). Cumania 11: 67-93.

A késő szarmata vasmüvesség nyomai Nyíregyháza-Rozsrét szőllő 36/c lelőhelyen. Poszter Hadak útja 26. konferencián.

Masek, Zs. 2012, Római császárkori települések Kántorjánosi és Pócspetri határában (Kaiserzeitliche Siedlungen in den Gemarkungen von Kántorjánosi und Pócspetri), in Szabó, Á., Masek, Zs. (eds.) Ante Viam Stratam. A Magyar Nemzeti Múzeum feltárásai Kántorjánosi és Pócspetri határában az M3-as autópálya nyomvonalán. Budapest: Magyar Nemzeti Múzeum.

Nepper, I. 1984. Császárkori szarmata telep Biharkeresztes Ártánd-Kisfarkasdombon (Die sarmatische Siedlung aus der Kaiserzeit, Gelegen auf dem Kisfarkas-Hügel). Debreceni Déri Múzeum Évkönyve (1981): 1-52.

Nepper, I. 1985. Császárkori szarmata telep Biharkeresztes Ártánd-Nagyfarkasdombon (Die sarmatische Siedlung aus der Kaiserzeit, Gelegen auf dem Kisfarkas-Hügel). Debreceni Déri Múzeum Évkönyve (1982): 101-249.

Pâslaru, I., Colesniuc, S. M., Ionescu M., Geraskova, L., Colțeanu, P., Dimache, M., Georgescu, Șt. V., Heroiu, A. and Petcu, R. 2011. Murani, com. Orțişoara, jud. Timiș Punct: Obiectivul nr. 04 de pe autostrada Arad Timişoara - km 29+500 - km 29+800, in Cronica Cercetărilor Arheologice din România, Campania 2010: 202-205. Sibiu: Muzeul Naţional Brukenthal.

Pădureanu, E. 1988. Așezări de sec. III-IV pe cursul inferior al Mureşului. Crisia 18: 381-406.

Párducz, M. 1960. Megjegyzések a Hódmezővásárhely-kakasszéki szarmatakori lelet értékeléséhez (Comments of the evaluation of the sarmatian finds from Hódmezővásárhely-Kakasszék), Archaeológiai Értesítő, 87: 51.

Rózsa, Z. 2005. Szarmata telep- és temetőrészlet Békéssámson, Erdőháti-halom lelőhelyen (Sarmatische Siedlung und sarmatisches Gräberfeld in Békéssámson, Erdőháti-halom). Szántó Kovács Múzeum Évkönyve 7: 49-84.

Rusu, R. 2007. Organizarea spatiului geografic in Banat. Timişoara: Editura Mirton.

Spânu, D. 2019. Poieneşti Necropola din secolele II-III. Cluj-Napoca: Editura Mega.

Szentmiklosi, S. and Timoc, C. 2015. Die Ersten Archäologische Ausgrabungen von Foeni, Ort "Seliște". Banatica 17: 59-73.

Tari, E. 2006. Régészeti kutatások másfél millió négyzetméteren, Autópálya és gyorsforgalmi utak építését megelözö régészeti feltárások Pest megyében 2001-2006. Szentendre: Kiadja a Pest Megyei Múzeumok Igazgatósága.

Vaday, A. 1981, Szarmata sírok Martfü, Zsófia majorban (Sarmatische Gräber im Zsófia-major bei Martfü). Szolnok Megyei Múzeum Évkönyve: 5-11. 
Vaday, A. 1988-89. Die sarmatischen Denkmäler des Komitats Szolnok. Ein Beitrag zur Archäologie und Geschichte des sarmatischen Barbaricums. Anteus 17-18.

Vaday, A. 1990-91. The dacian questions in the Sarmatian Barbaricum. Antaeus 19-20: 75-82.

Vaday, A. 1999. A szarmata telep értékelése, in Petercsák, T., Szabó, J. (eds.) Kompolt-Kistér: újkőkori, bronzkori, szarmata és avar lelőhely: leletmentő ásatás az M3-as autópálya nyomvonalán: 179-232. Eger: Dobó István Vármúzeum.

Vaday, A. 2004, Some data on the barbarian settlement research in Hungary. Študijné zvesti. Archeologického ústavu Slovenskej akadémie 36: 211-218.

Vaday, A. 2005. Adatok a szarmaták fémmüvességéhez (Tiszaföldvár-Téglagyár) / Angabe zur Metallurgie der Sarmaten (Tiszaföldvár-Téglagyár/Ziegelei). Szántó Kovács Múzeum Évkönyve 7: 161-198.

Vaday, A. and Szekeres, Á. 2001. Megjegyzések az Alföld korai szarmata telepeinek kérdéséhez (A jazyg bevándorlás és megtelepedés kérdésköre) / Bemerkungen zur Frage der frühsarmatischen Siedlungen in Tiefebene (Der Fragenkreis der Jazygischen Einwanderung und Ansiedlung). Móra Ferenc Múzeum ÉvkönyveStudia Archaeologica 7: 231-298.

Visy, Zs. 1970. Die Daker am Gebiet von Ungarn. Móra Ferenc Múzeum Évkönyve: 5-29.

Vörös, G. 1998. Telepüésszerkezet és életmód az alföldi szarmaták falvainban, in Havassy, P. (ed.) Gyulai katalógusok 6, Jazigok, roxolánok, alánok, Szarmaták az Alföldön: 49-66. Gyula: Erkel Ferenc Múzeum.

Zdroba, M. and Barbu, M. 1976. Săpăturile arheologice de la Felnac şi Vladimirescu (Rapoarte preliminare). Ziridava VI: 47-55.

\section{LIST OF ILLUSTRATIONS}

Fig. 1. Location of site $B \_06$ at Arad.

Fig. 2. Orthophotoplan with the location of site $B \_06$.

Fig. 3. Location of features within the investigated area of site $B \_06$.

Fig. 4. Map of recent finds of Sarmatian graves and cemeteries in the area south and north the Lower Mureș.

Fig. 5. Overall images of site $B \_06$ area after the performance of archaeological excavations.

Fig. 6. Overall images of site $B \_06$ area after the performance of archaeological excavations.

Fig. 7. Tronconical pits in the Arad settlment $B \_06$.

Fig. 8. Bronze ring (1-Cx 41) and fast wheel-thrown pottery from features $(2,4,5-\mathrm{Cx} 41 ; 3-\mathrm{Cx} 76 ; 6-\mathrm{Cx} 85 ; 7-$ Cx78).

Fig. 9. Handmade pottery, coarse (1, 3, 4- Cx41; 2-Cx49).

Fig. 10. Handmade pot, coarse (Cx41).

Fig. 11. Handmade pot, coarse (Cx91).

Fig. 12. Blacksmiths iron pliers (Cx111).

VITALIE BÂRCĂ Institute of Archaeology and Art History, Cluj-Napoca vitalie_barca@yahoo.com 


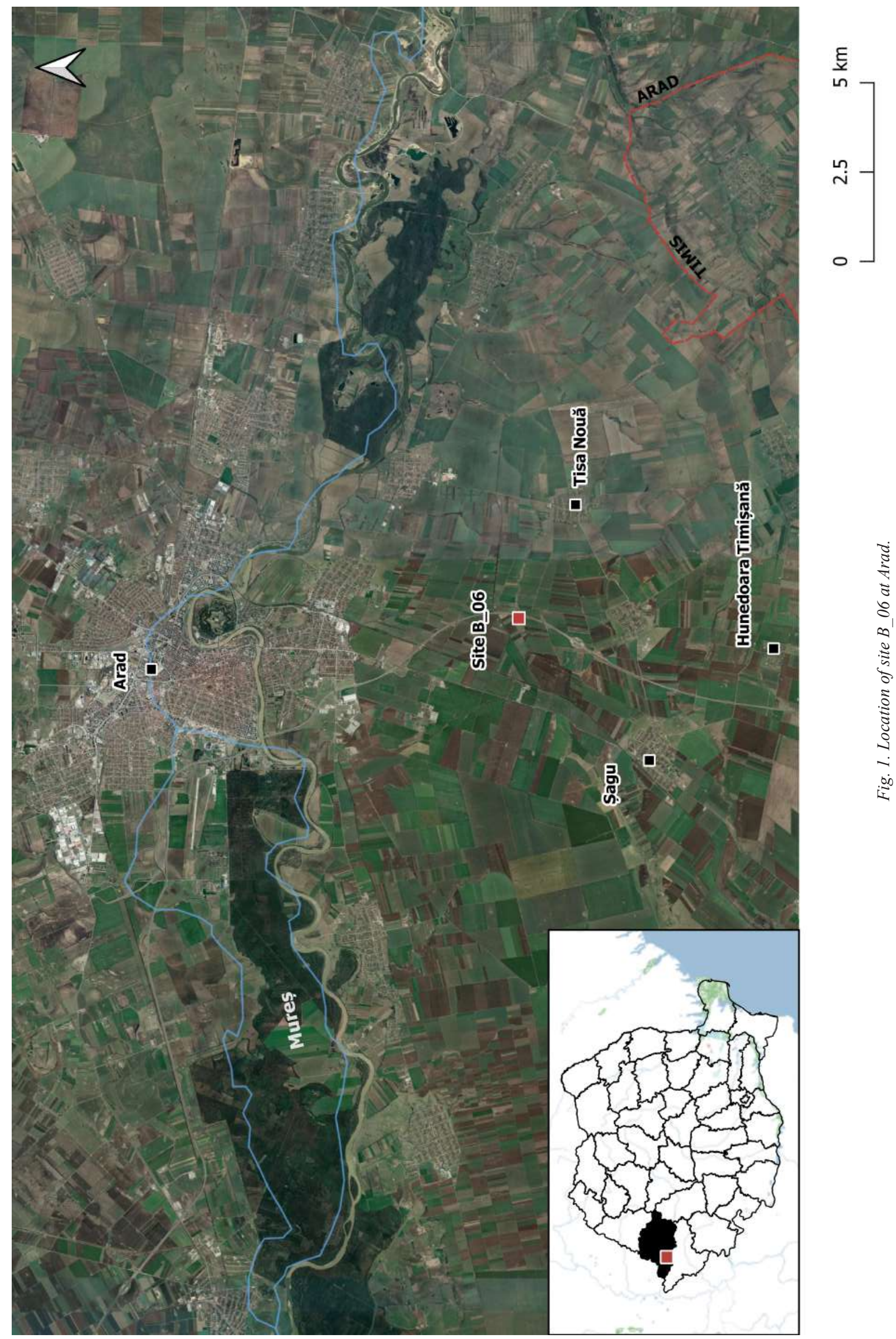




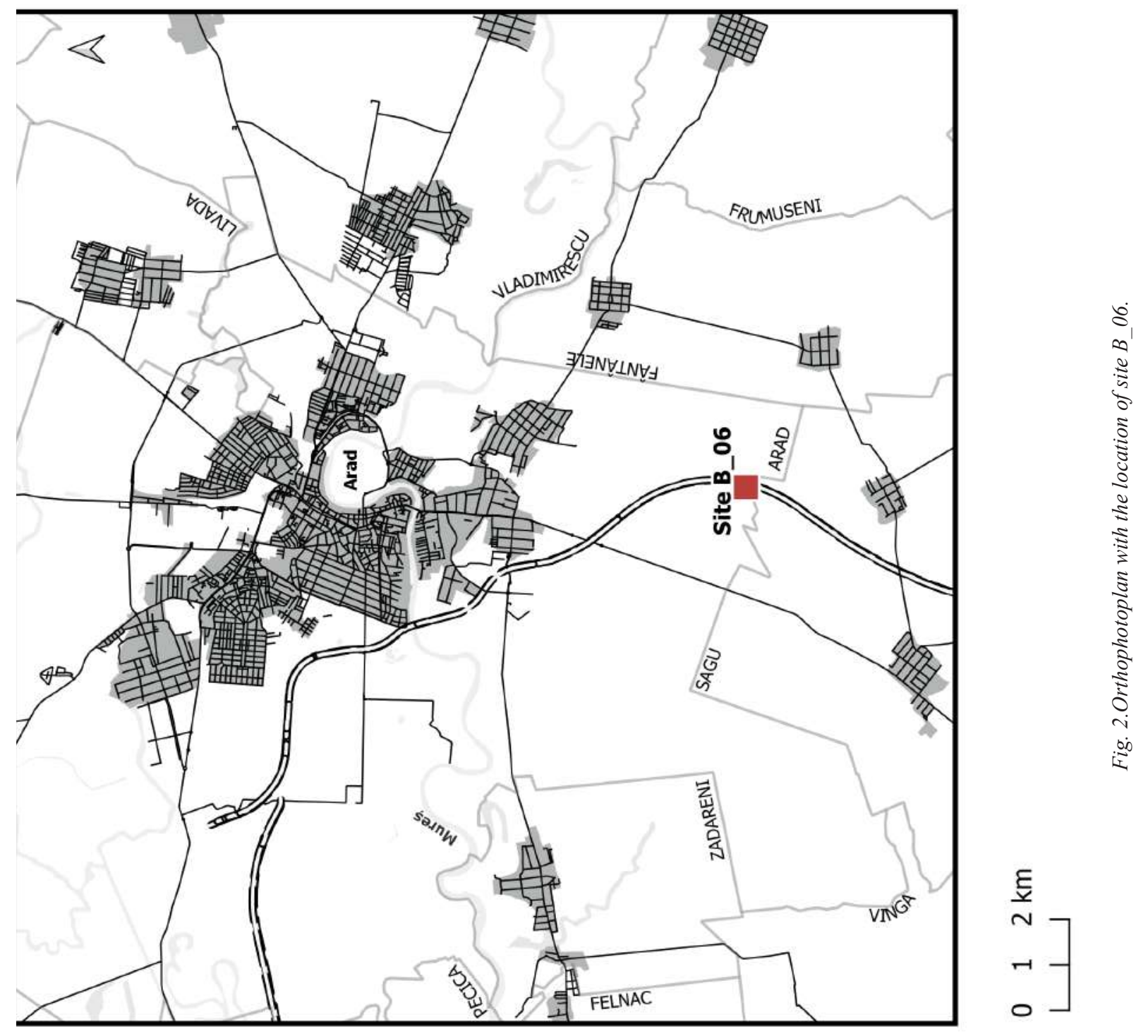




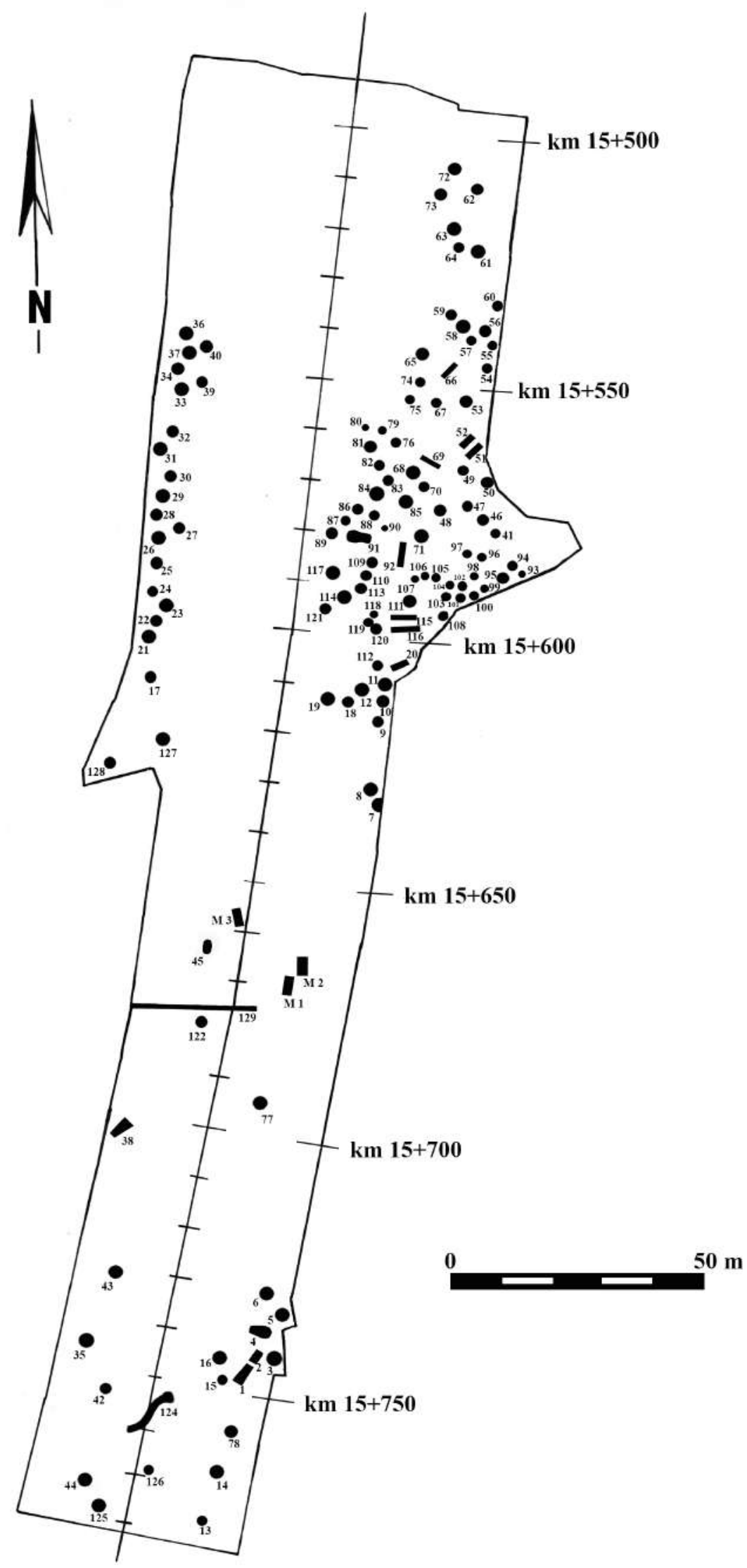




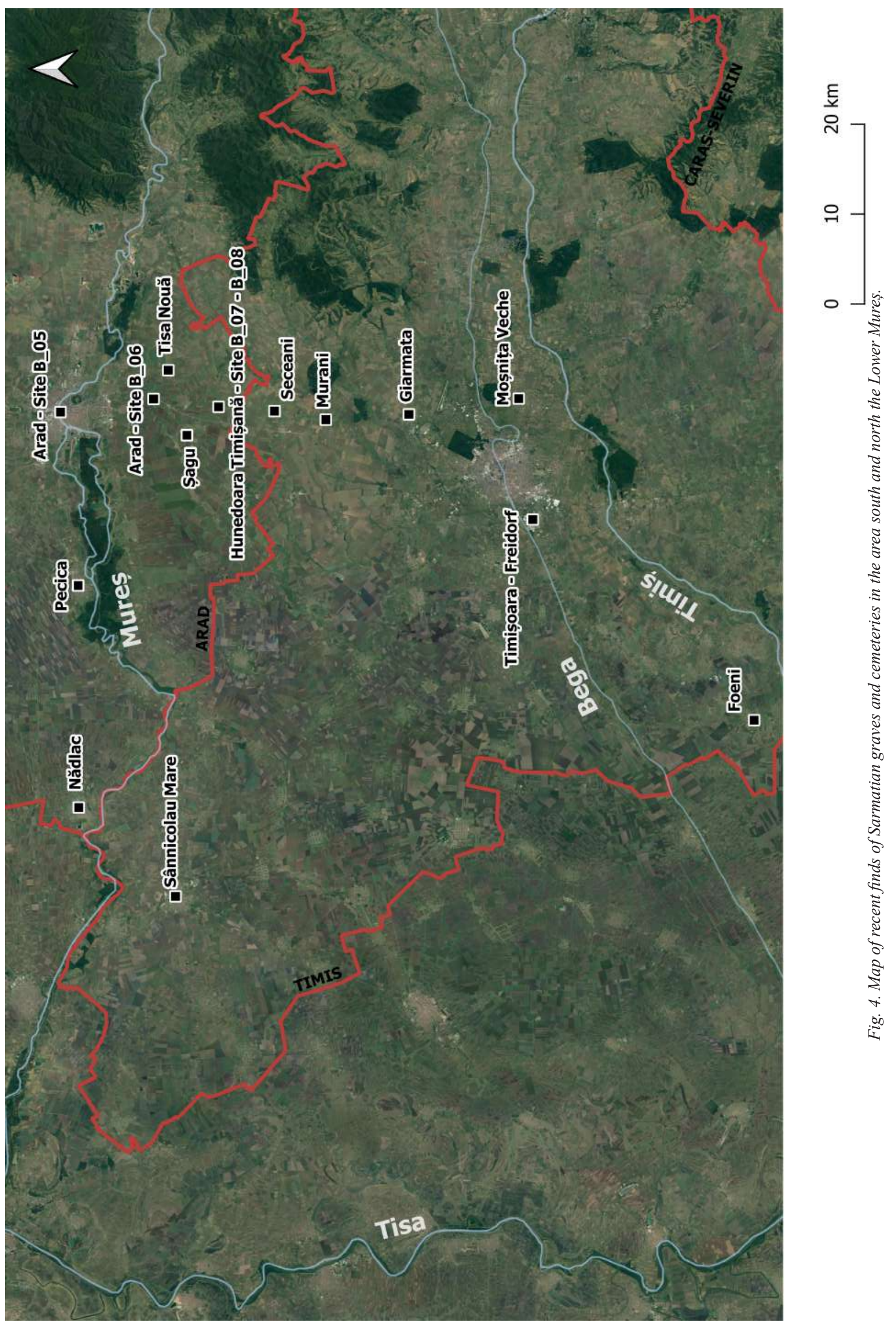




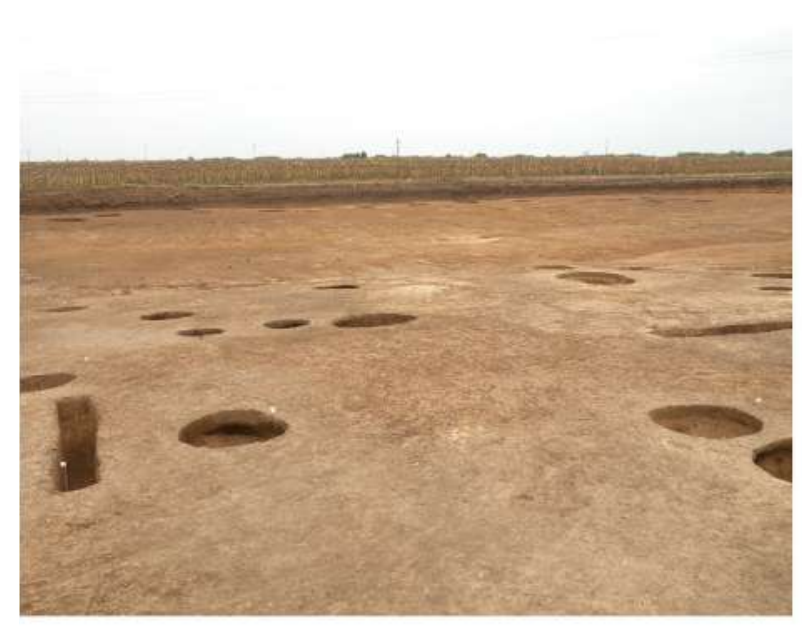

1

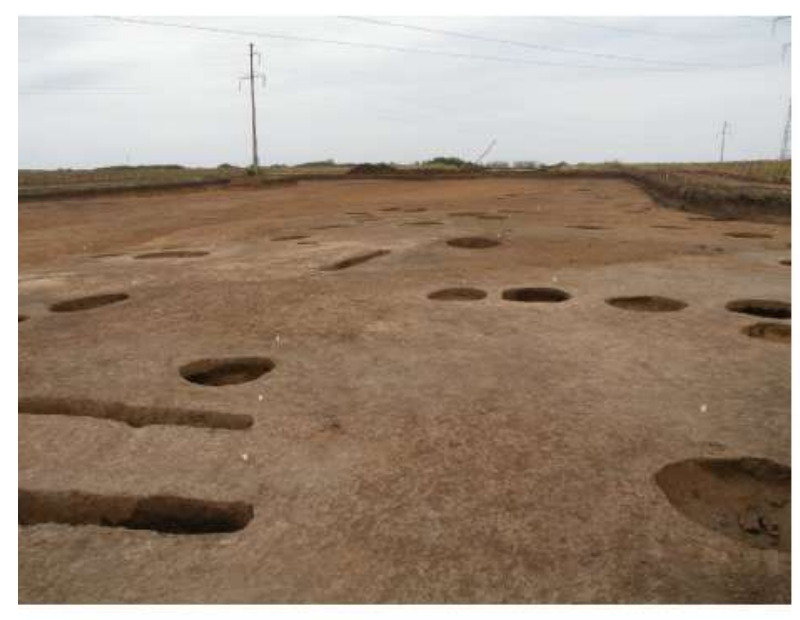

3

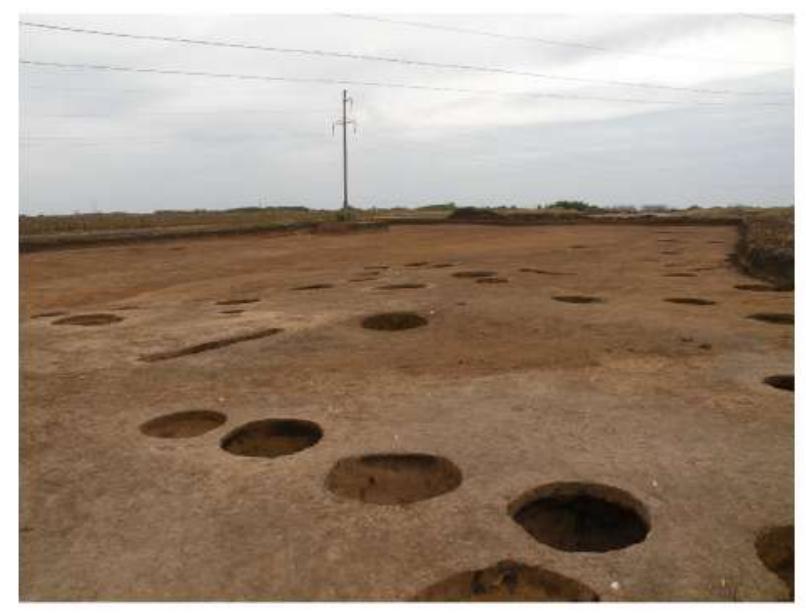

5

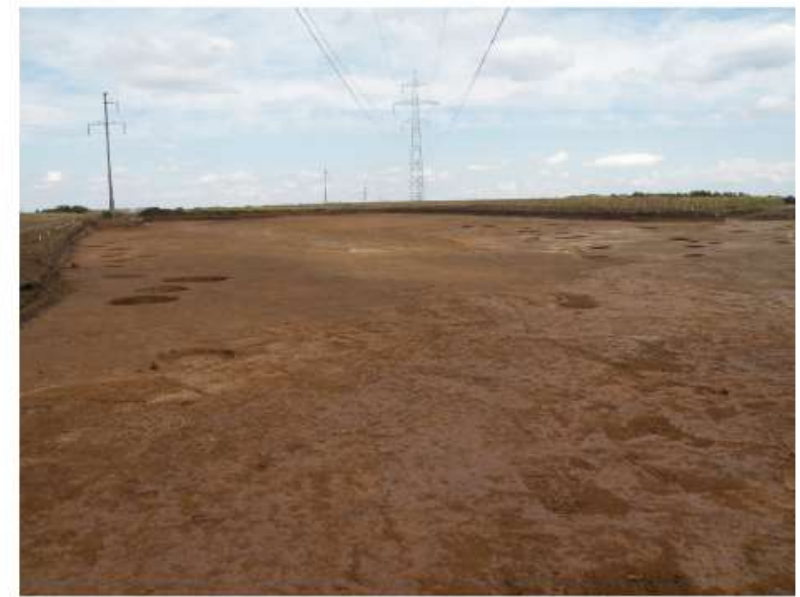

2

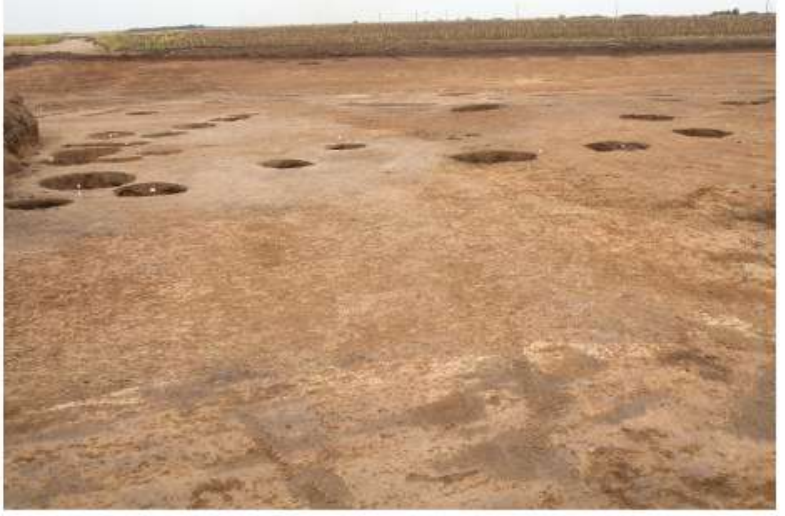

4

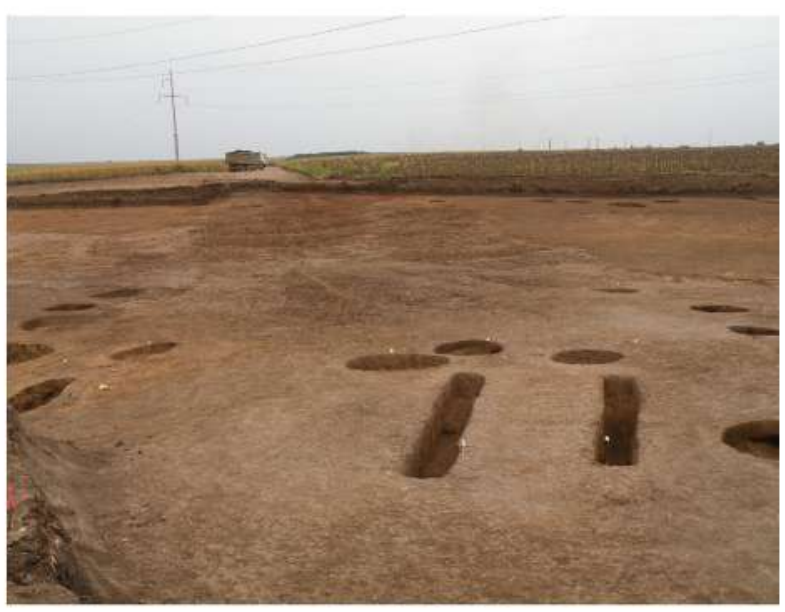

6

Fig. 5. Overall images of site B_06 area after the performance of archaeological excavations. 


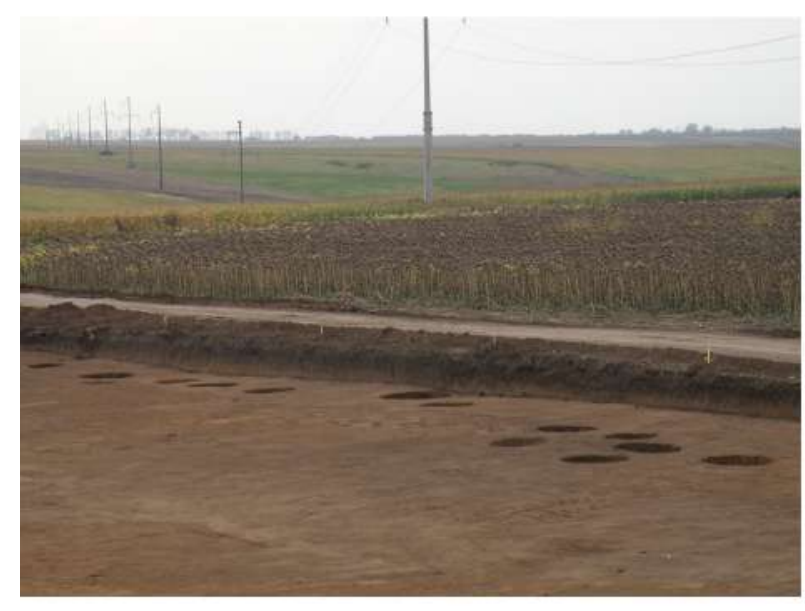

1

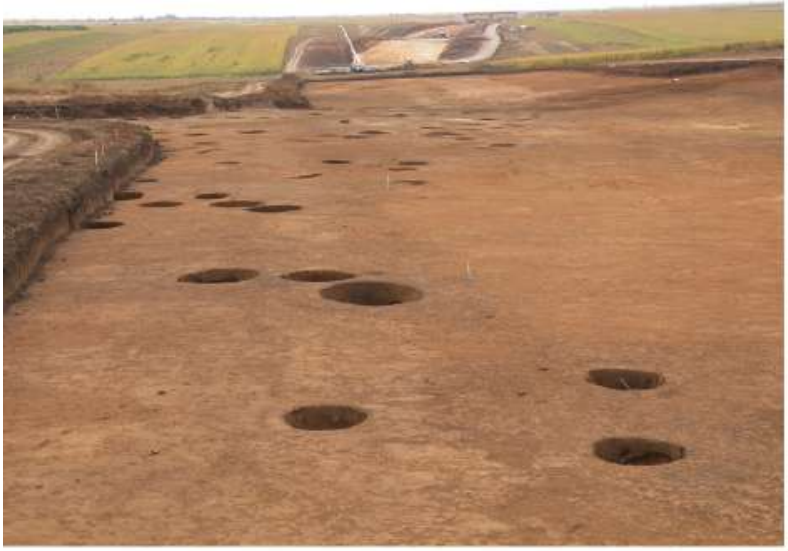

3

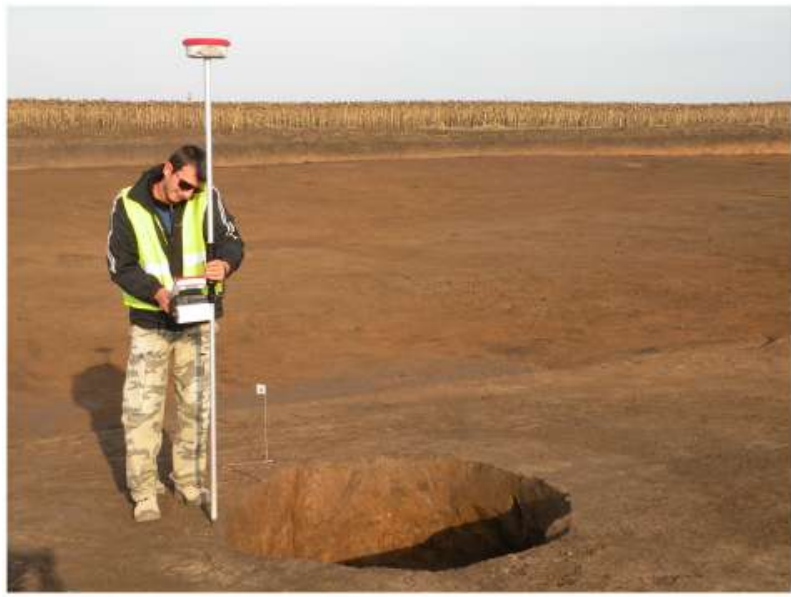

5

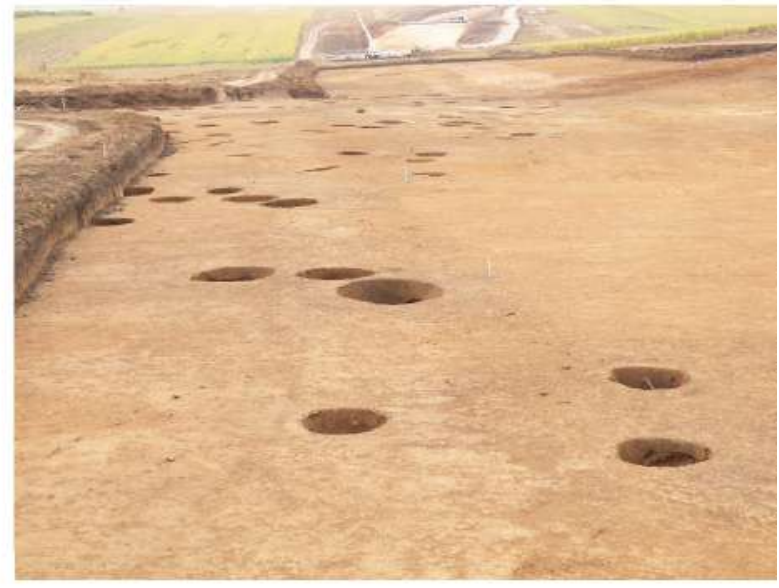

2

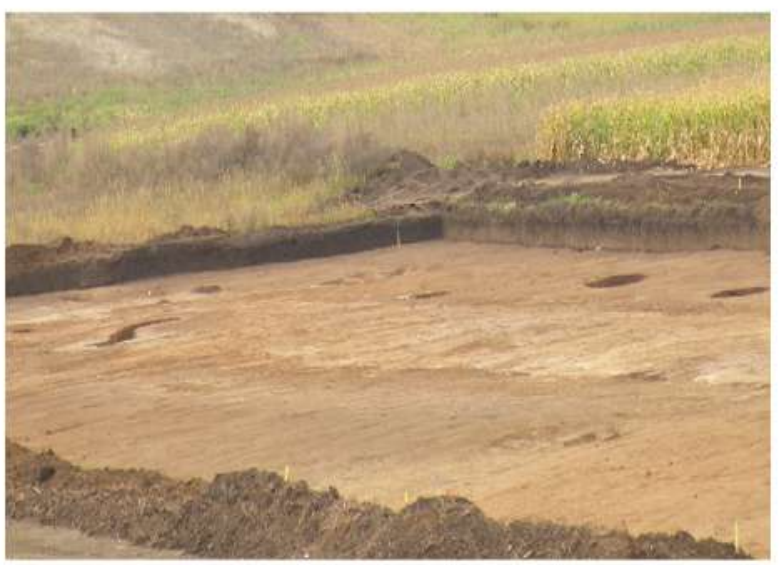

4

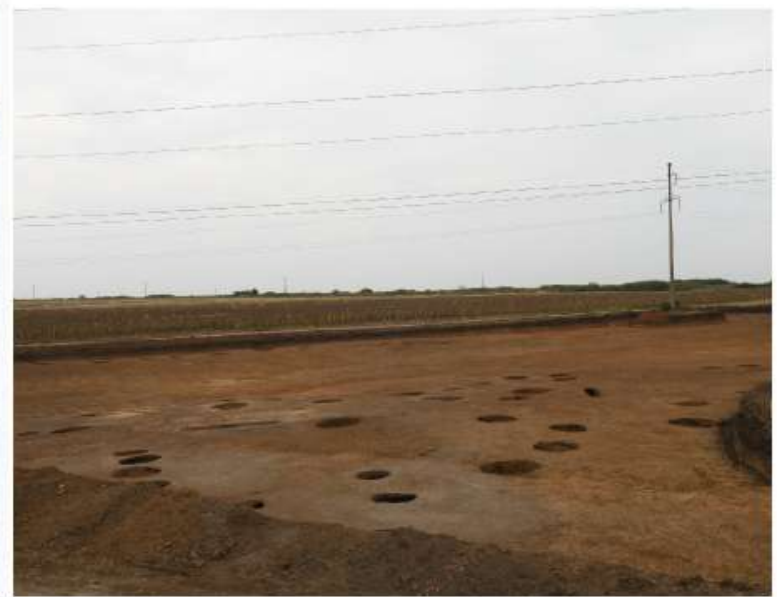

6

Fig. 6. Overall images of site $B \_06$ area after the performance of archaeological excavations. 
85

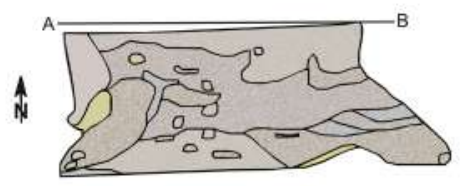

Cx 50

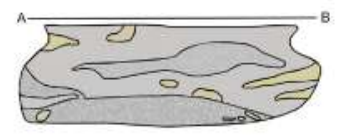

Cx 61

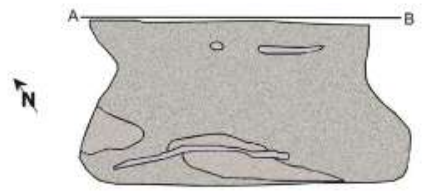

Cx 110

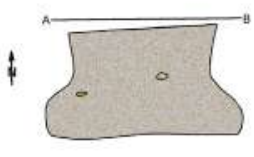

Cx 75

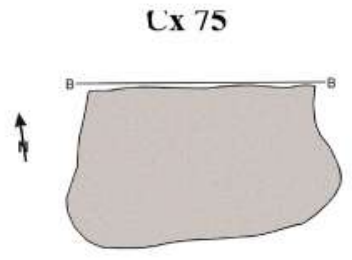

Cx 54
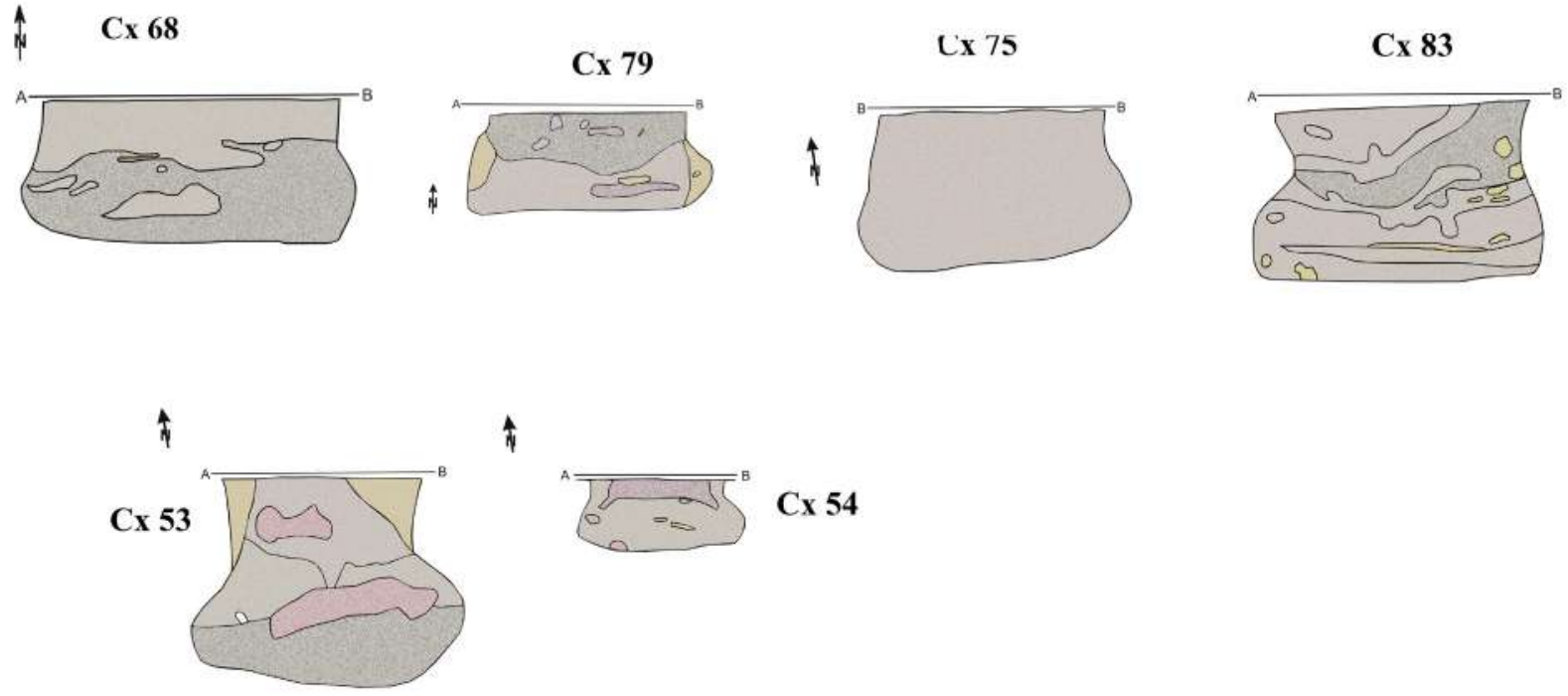

$\uparrow$

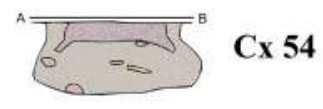

Cx 60

Cx 57
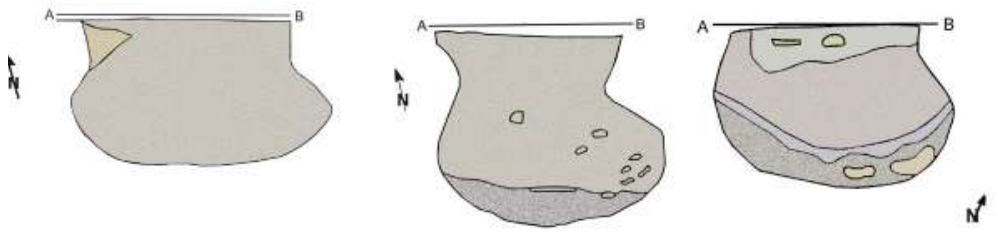

Cx 96

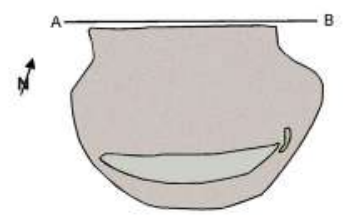

Cx 97
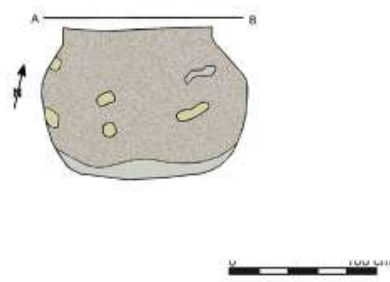

Fig. 7. Tronconical pits in the Arad settlment B_06. 

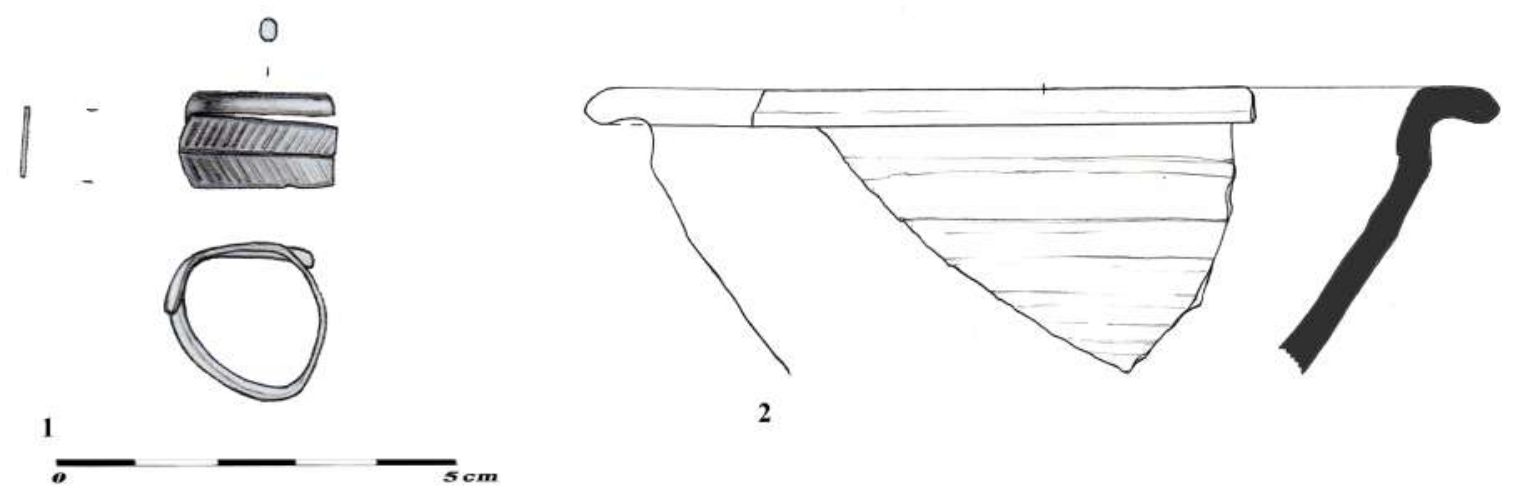

2
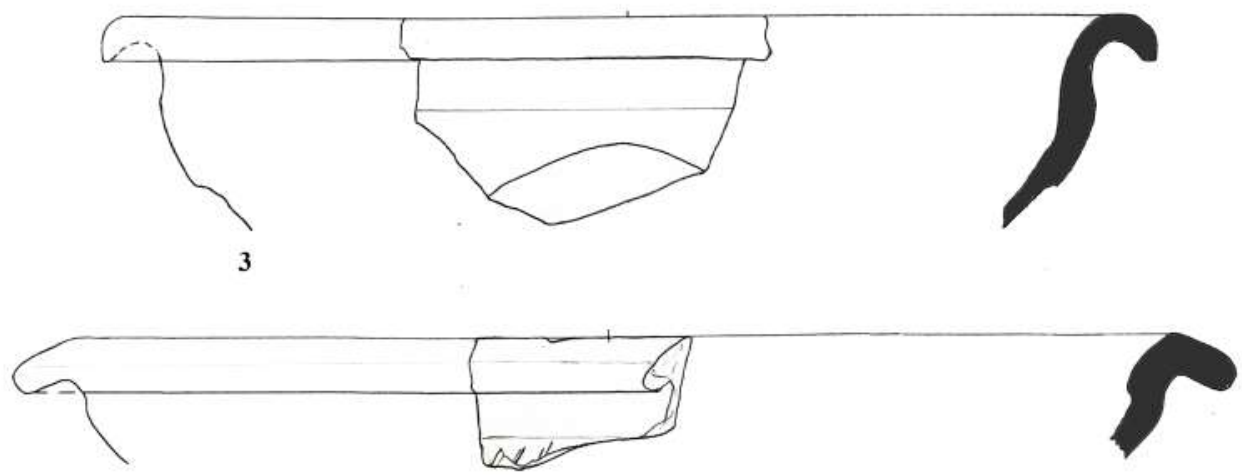

4

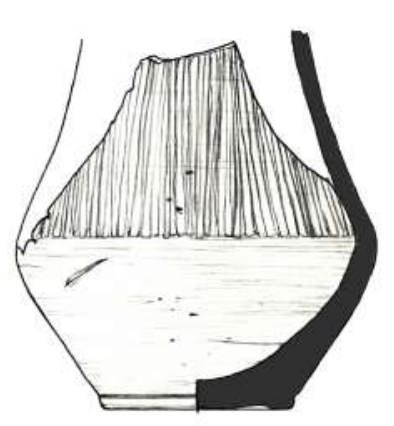

5

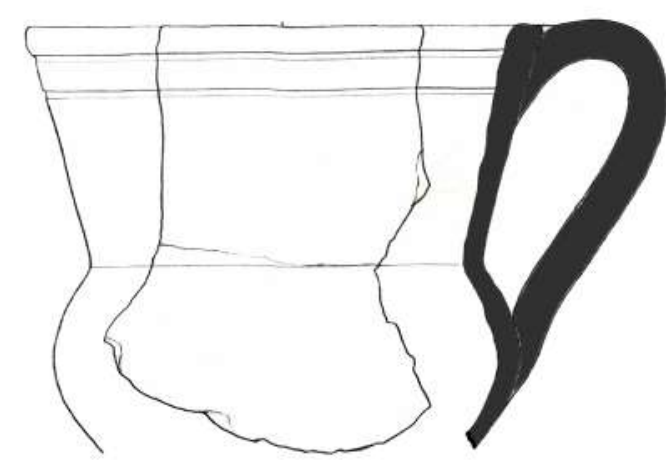

6

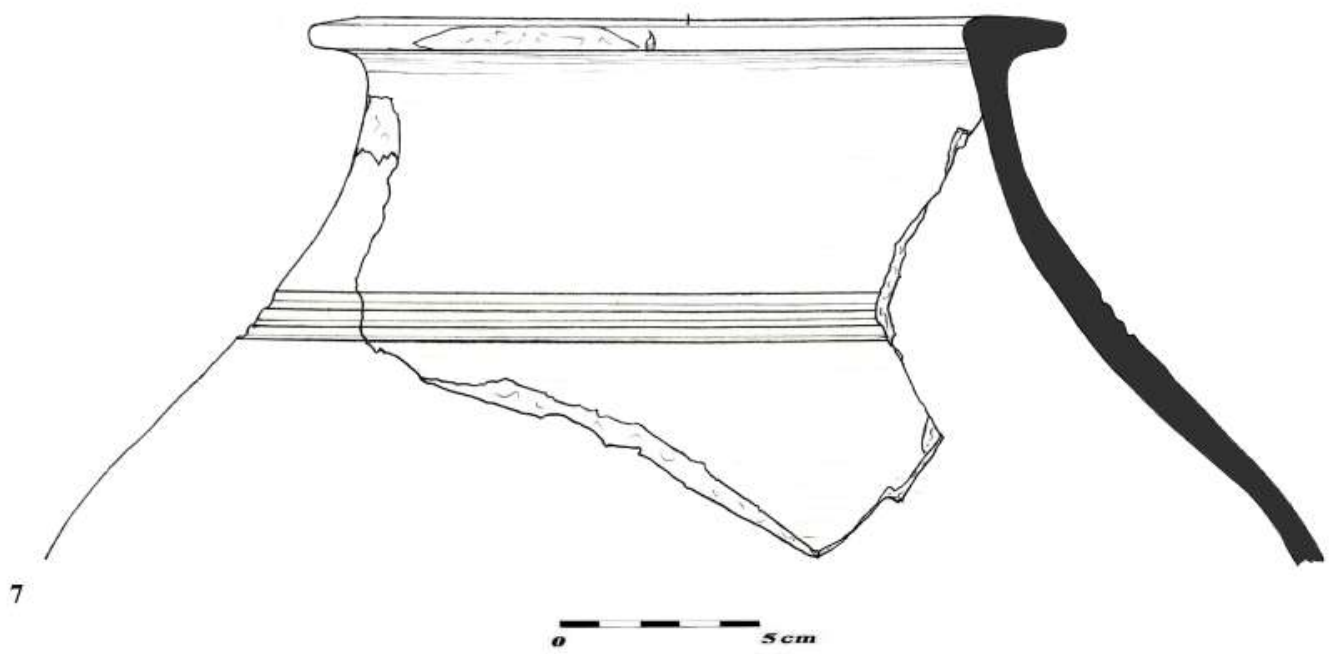

Fig. 8. Bronze ring (1-Cx 41) and fast wheel-thrown pottery from features $(2,4,5-C x 41$; 3- Cx 76; 6-Cx 85;7-Cx78). 

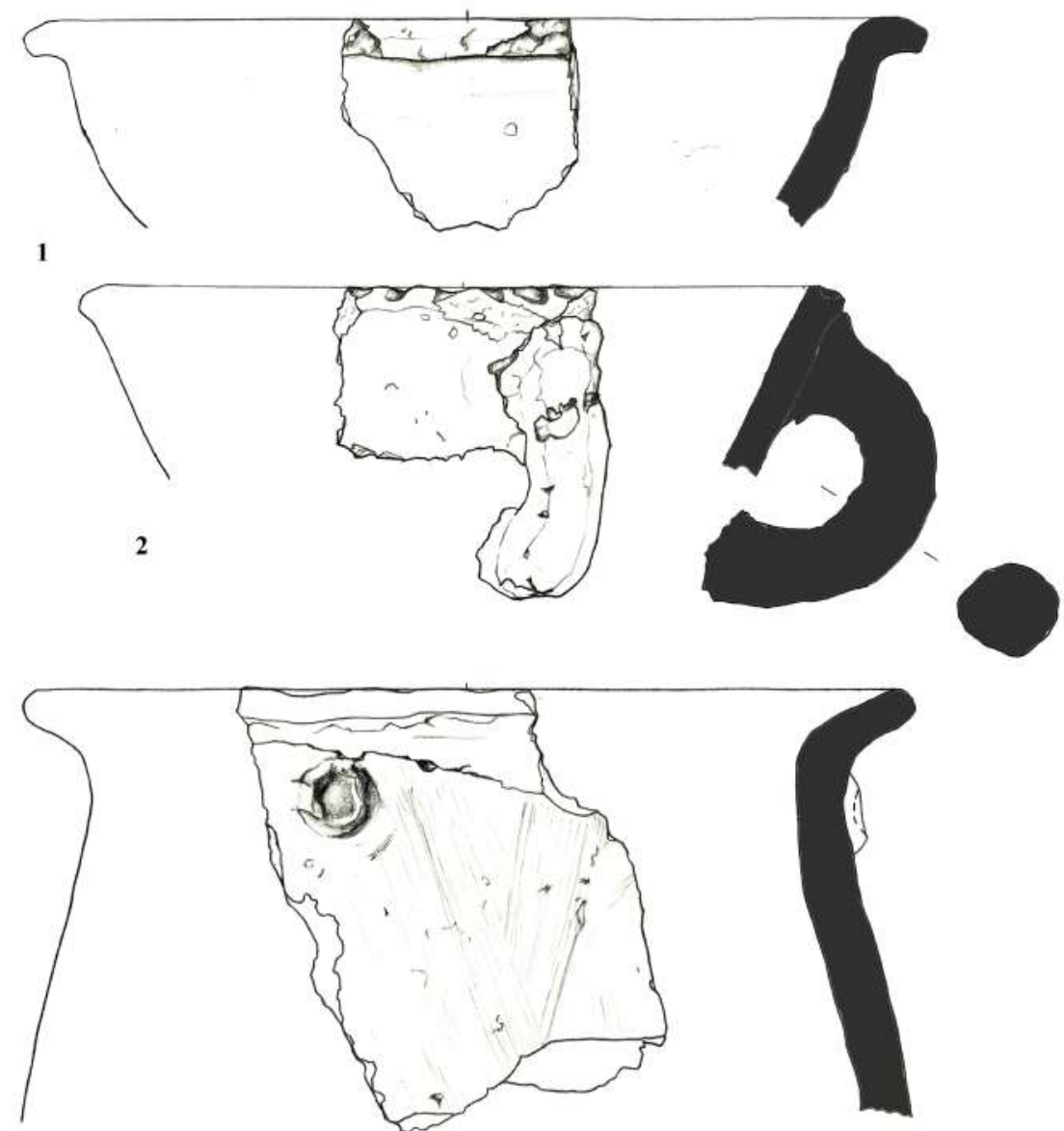

3

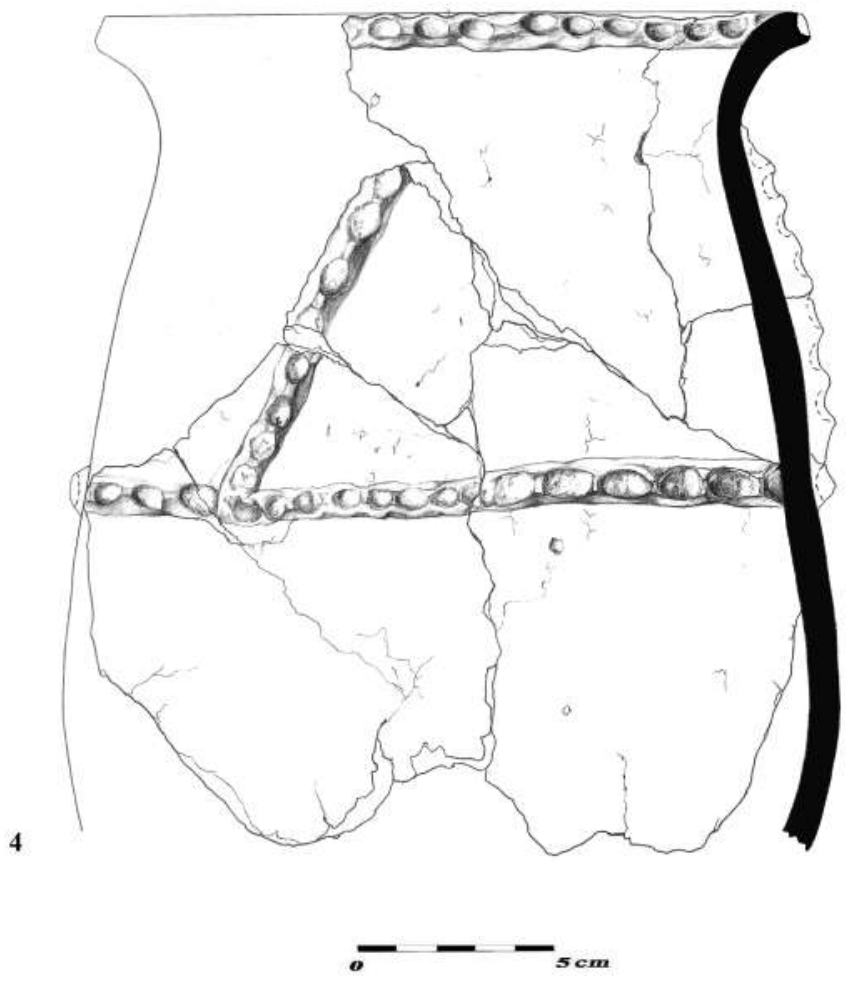

Fig. 9. Handmade pottery, coarse (1, 3, 4-Cx41; 2-Cx49). 


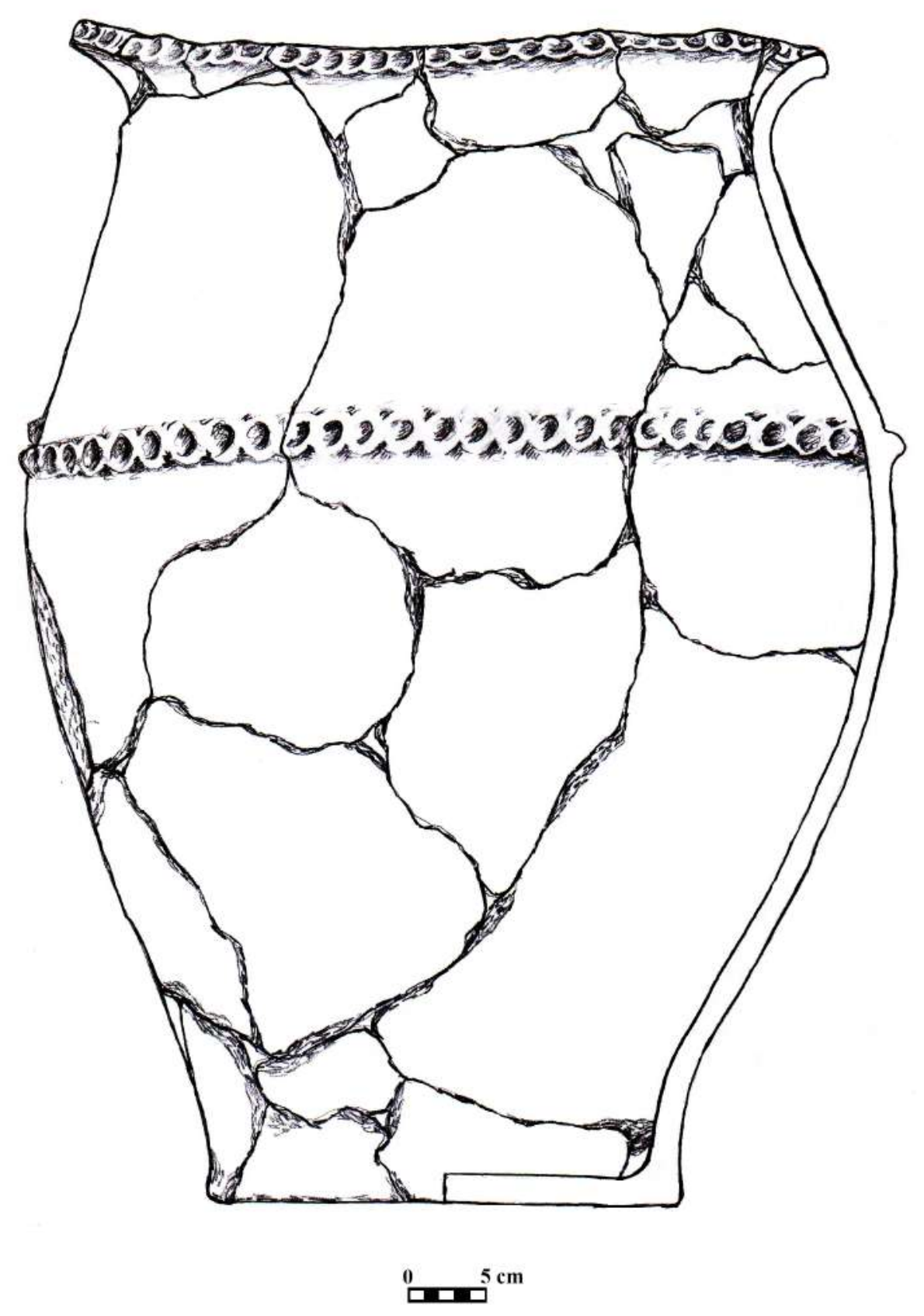

Fig. 10. Handmade pot, coarse (Cx41). 

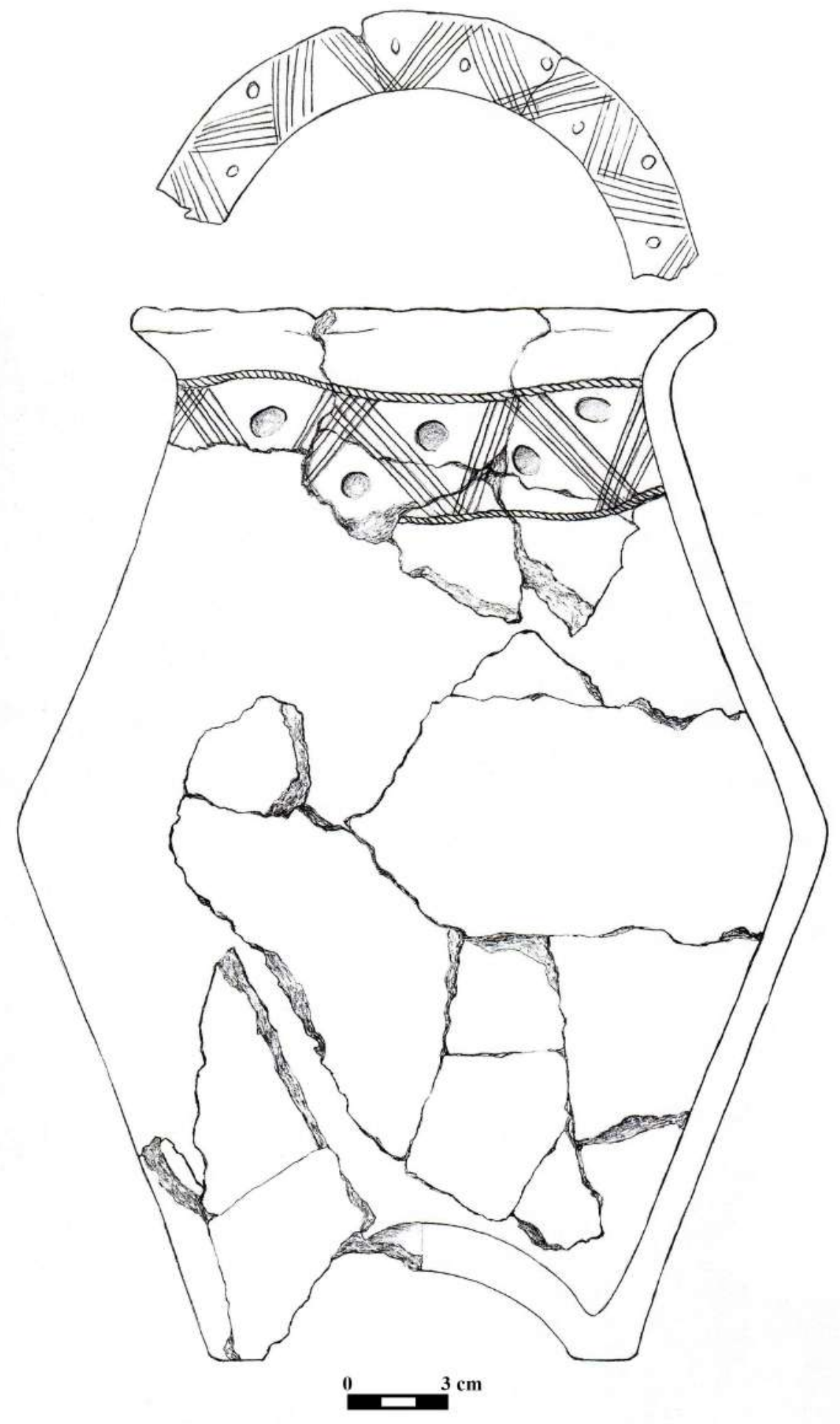

Fig. 11. Handmade pot, coarse (Cx91). 


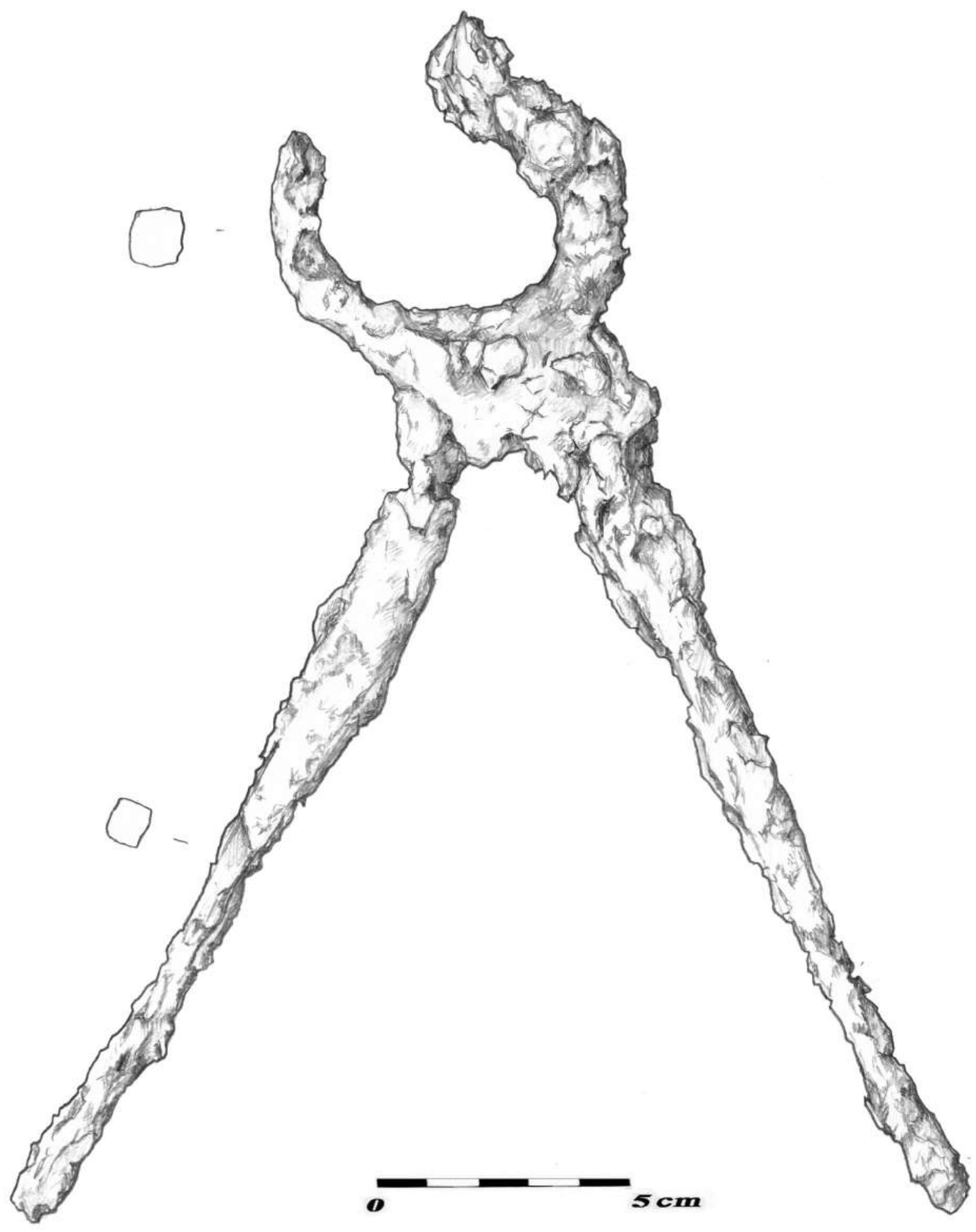

Fig. 12. Blacksmiths iron pliers (Cx111). 
